Revista Eletrônica de Direito Processual - REDP.

Rio de Janeiro. Ano 13. Volume 20. Número 1. Janeiro a Abril de 2019

Periódico Quadrimestral da Pós-Graduação Stricto Sensu em Direito Processual da UERJ

Patrono: José Carlos Barbosa Moreira (in mem.). ISSN 1982-7636. pp. 532-566 www.redp.uerj.br

\title{
A AMPLITUDE DE IMPUGNAÇÃO NA AÇÃ̃ RESCISÓRIA: DECISÃO PARCIAL, COISA JULGADA PREJUDICIAL, CAPÍTULOS DA DECISÃO E COISA JULGADA PROGRESSIVA ${ }^{1}$
}

\section{THE AMPLITUDE OF IMPUGNATION IN ACTION OF TERMINATION: PARTIAL DECISION, RES JUDICATA RULING, CHAPTERS OF THE DECISION AND PROGRESSIVE RES JUDICATA}

Vinicius Silva Lemos Advogado. Doutorando em Direito Processual pela UNICAP/PE. Mestre em Sociologia e Direito pela UFF/RJ. Especialista em Processo Civil pela FARO. Professor de Processo Civil na FARO e UNIRON. Coordenador da PósGraduação em Processo Civil da Uninter/FAP. VicePresidente do Instituto de Direito Processual de Rondônia IDPR. Membro da Associação Norte-Nordeste de Professores de Processo - ANNEP. Membro do Centro de Estudos Avançados em Processo - CEAPRO. Membro da Academia Brasileira de Direito Processual Civil - ABDPC. Membro da Associação Brasileira de Direito Processual - ABDPRO. Email: viniciuslemos.ro@gmail.com

RESUMO: Este artigo visa analisar o instituto da ação rescisória e os impactos que o CPC/2015 proporcionou na ampliação da cognição e a possibilidade de impugnações parciais. Analisamos, primeiramente, toda a conceituação natureza jurídica, objeto, pressupostos, legitimados, competência e a relação com a coisa julgada parcial, mediante os institutos decisórios previstos no novel ordenamento processual.

PALAVRAS-CHAVE: Ação Rescisória; Coisa Julgada; Decisão Parcial; Coisa Julgada Prejudicial

\footnotetext{
${ }^{1}$ Artigo recebido em 20/05/2018 e aprovado em 30/07/2018.
} 
Revista Eletrônica de Direito Processual - REDP.

Rio de Janeiro. Ano 13. Volume 20. Número 1. Janeiro a Abril de 2019

Periódico Quadrimestral da Pós-Graduação Stricto Sensu em Direito Processual da UERJ

Patrono: José Carlos Barbosa Moreira (in mem.). ISSN 1982-7636. pp. 532-566

www.redp.uerj.br

ABSTRACT: This article aims to analyse the institute of action of termination and the impacts that the $\mathrm{CPC} / 2015$ resulted in the expansion of cognition and the possibility of partial challenges. First, we analysed all the conceptualization legal nature, object, assumptions, legitimised, competence and the relationship with partial res judicata in part by the decision-making institutions provided for in the novel planning procedure.

KEYWORDS: Action of termination; Progressive Res Judicata; Partial Decision, Res Judicata Ruling.

\section{INTRODUÇÃO}

O CPC/2015 impactou o ordenamento processual desde sua sanção e, posteriormente, com a sua vigência toda a comunidade jurídica, com o incremento de diversas novidades e alterações em institutos outrora conhecidos, como, no caso do presente estudo, a ação rescisória.

A ação rescisória é uma lide que visa desconstituir e relativizar a coisa julgada material, sendo um meio de garantir a estabilidade do ordenamento jurídico e, ainda, possibilitar a ausência de vícios processuais e permitir uma maior segurança jurídica.

O instituto não foi alterado em sua base conceitual ou sua percepção geral, contudo foi impactado com diversos pontos, desde adaptações de hipóteses de cabimento até a amplitude do alcance da impugnação material da própria ação rescisória.

Delimitamos o objeto desse estudo como a relação da ação rescisória, sua nova visão de amplitude com a intersecção com as variações cognitivas, principalmente as cisões ou incidentes das decisões judiciais, como a decisão parcial de mérito, a coisa julgada prejudicial e a coisa julgada parcial, relacionando com a coisa julgada progressiva.

O objetivo dessa revisão bibliográfica e pesquisa dogmática é delinear as novidades que impactam a amplitude de impugnação da ação rescisória e as novidades sobre as cognições incidentais, bem como enfrentar os aspectos da coisa julgada prejudicial. 


\section{AÇÃO RESCISÓRIA NO CPC/2015}

A ação rescisória tem um caráter constitutivo negativo para, nas hipóteses do art. 966, impugnar sentença/decisão de mérito, transitada em julgado, para desconstituir a coisa julgada material, para fins de rescisão e prolação de nova decisão, quando assim for necessário.

É uma forma de impugnação de uma decisão ${ }^{2}$, nesse caso, transitada em julgado $^{3}$. Uma ação autônoma de impugnação ${ }^{4}$, com base em alguma hipótese de vício existente naquele processo que transitou em julgado, possibilitando uma reanálise da validade do processo e da decisão anterior, para fins de possível rescisão e, se for o caso, uma reanálise do mérito ${ }^{5}$ da demanda anterior.

A finalidade de existência da ação rescisória é a possibilidade de resguardar a segurança jurídica. A lei estipula que certos vícios são tão graves que, mesmo diante da formação de coisa julgada material, revestida de imutabilidade, podem ser relativizadas, contudo somente nesses casos e situações determinadas em lei.

Não se pode deparar com alguns vícios graves dentro de uma demanda, mesmo transitada em julgado, deixando-os produzir efeitos no ordenamento jurídico. Se houver a ocorrência de tais vícios, tais situações processuais, a decisão daquela demanda que já se encerrou, pode ser revista pela ação rescisória. Situações como um crime do juiz na demanda, um dolo de uma parte, uma ameaça, dentre outros vícios que veremos mais a frente, são vícios não poderiam continuar a produzir efeitos jurídicos, possibilitando a sua rescisão e eventual retirada de sua eficácia jurídica.

\footnotetext{
2 "é a ação por meio da qual se pede a desconstituição de sentença transitada em julgado, com eventual rejulgamento, a seguir, da matéria nela julgada” MOREIRA, José Carlos Barbosa. Comentários ao código de processo civil. 7. ed. Rio de Janeiro: Forense, v. 05, 1998. p. 100.

3 "a ação rescisória como demanda autônoma de impugnação de provimentos de mérito transitados em julgado, com eventual rejulgamento da matéria neles apreciada." CÂMARA, Alexandre Freitas. Ação rescisória. Rio de Janeiro: Lumen Juris, 2007. p. 30.

4 "de competência originária dos tribunais, a ação rescisória é meio processual hábil a impugnar decisões de mérito proferidas com vícios graves (com exceção do documento novo), revestidas pela autoridade da coisa julgada" CARVALHO, Fabiano. Ação Rescisória: decisões rescindíveis. São Paulo: Saraiva, 2010. p. 21.

5 "a qual poderá trazer em seu bojo duas pretensões diversas: a rescindente (iusrescindens), que se refere ao pedido de desconstituição da coisa julgada, e a rescisória (iusrescissorium), que é o pedido de rejulgamento da causa, quando for o caso. " TALAMINI, Eduardo; WAMBIER, Luiz Rodrigues. Curso avançado de processo civil: teoria geral do processo e processo de conhecimento. 11. ed. São Paulo/SP: Revista dos Tribunais, 2010. p. 751.
} 
Desse modo, abre uma possibilidade de rescisão para resguardar a segurança jurídica, retirando a coisa julgada viciada, de modo tão grave, que não se pode admitir a sua persistência, naquele momento, como coisa julgada e sua produção de efeitos jurídicos.

Por outro lado, se a segurança jurídica deve ser resguardada, possibilitando a relativização da coisa julgada material, caso exista vício grave em determinada demanda, há de se impor limites temporais para essa arguição de eventual nulidade, para, de igual modo, resguardar a segurança jurídica. Ao mesmo tempo em que a existência de um vício dessa magnitude merece ser extirpada do processo, retirando sua validade e julgando-o novamente, essa arguição não pode ser ilimitada temporalmente. Há de ter um prazo, uma delimitação para a suscitação dos vícios.

Ou seja, a segurança jurídica possibilita a existência da ação rescisória para a anulação de decisão judicial viciada e, de igual maneira, a própria segurança jurídica impede que tal decisão, mesmo que eivada de vício, possa ser impugnada ad eternum, infinitamente. Necessariamente, um prazo deve ser estipulado. Até pelo fato de uma decisão de mérito viciada transitada em julgado, mesmo possível de anulação pelo vício existente, necessita de, em algum momento, revestir-se de uma imutabilidade absoluta, caso não tenha uma impugnação por um período determinado de tempo.

\subsection{Natureza jurídica da ação rescisória}

A ação rescisória é dotada de natureza jurídica de ação, por inaugurar um novo procedimento, uma nova demanda, com todas as características necessárias para tanto. Estão presentes as necessidades da adequação à petição inicial, um processamento que prima pelo contraditório, bem como um possível estágio probatório, culminando em uma análise cognitiva pelo julgador, com a procedência ${ }^{6}$ ou não da demanda.

\footnotetext{
6 "A adoção do termo desconstituição para designar o objetivo da ação rescisória parece mais adequado porque guarda correspondência com a sentença constitutiva, espécie de sentença admitida pela doutrina e jurisprudência. Como se sabe, a sentença constitutiva promove a modificação de uma situação jurídica, sendo exatamente isso o que ocorre quando o pedido rescindente é julgado procedente." CRAMER, Ronaldo. Comentário ao art. 966. CABRAL, Antonio Passo, CRAMER, Ronaldo (orgs.). Comentários ao novo código de processo civil, $2^{\mathrm{a}}$ edição. Método, 06/2016. [Minha Biblioteca]. Retirado de https://integrada.minhabiblioteca.com.br/\#/books/9788530971441/
} 
Revista Eletrônica de Direito Processual - REDP.

Rio de Janeiro. Ano 13. Volume 20. Número 1. Janeiro a Abril de 2019

Periódico Quadrimestral da Pós-Graduação Stricto Sensu em Direito Processual da UERJ

Patrono: José Carlos Barbosa Moreira (in mem.). ISSN 1982-7636. pp. 532-566

www.redp.uerj.br

Todas as formalidades e atos jurídicos de uma ação estão presentes na rescisória com a sua natureza de abertura de uma nova demanda. O fato de impugnar uma decisão, contendo como mérito a busca pela rescisão, não a transforma em recurso, somente tem um pedido meritório diferente de outras demandas, tampouco está presente no rol dos recursos do CPC/2015, nem prolonga os efeitos da decisão que impugna, não podendo ser considerada, dessa maneira, um recurso.

A ação rescisória faz nascer nova demanda, em competência originária de um Tribunal, considerando, em regra, aquele onde foi proferida a decisão impugnada, com um necessário julgamento, um novo processo de conhecimento, mediante contraditório, com todas as suas características de uma demanda?

\subsection{Pressupostos da ação rescisória}

A ação rescisória, para ser possível, tem que preencher os pressupostos para sua existência, que permitem a rediscussão de uma decisão de mérito transitada em julgado. A possibilidade rescisória, como um todo, não é regra, somente em situação excepcional, quando presente uma conjunção de fatores, com um embasamento profundo, que permitam uma reanálise, tanto pela possível rescisão, quanto pelo posterior novo julgamento.

Com a configuração de todos os pressupostos $^{8}$, há o cabimento da ação rescisória. Em caso de ausência de um desses, obviamente, não há possibilidade de interposição do pleito de rescisão.

\subsubsection{Objeto da ação rescisória: decisão}

\footnotetext{
7 “A ação rescisória é a ação autônoma de impugnação, que tem por objetivos a desconstituição de decisão judicial transitada em julgado e, eventualmente, o rejulgamento da causa. Ela não é recurso, exatamente porque dá origem a um novo processo para impugnar a decisão judicial. A ação rescisória pressupõe a coisa julgada, contrariamente ao recurso, que impede o trânsito em julgado e mantém o estado de litispendência ou de pendência do processo." CUNHA, Leonardo José Carneiro da; DIDIER JR., Fredie. Curso de direito processual civil Meios de impugnação às decisões judiciais e processo nos tribunais. $13^{\mathrm{a}} \mathrm{ed}$. Salvador: JusPodivm, 2016. p. 421.

8 "O ajuizamento da ação rescisória está condicionado à existência de três requisitos fundamentais: a) decisão judicial de mérito (ou que não permita a repropositura da demanda, ou que, ainda, impeça o reexame do mérito pelo tribunal) transitada em julgado; b) invocação razoável de um dos fundamentos rescisórios; e c) propositura dentro do prazo decadencial". WAMBIER, Teresa Arruda Alvim. CONCEIÇÃO, Maria Lúcia Lins. RIBEIRO, Leonardo Ferres da Silva. MELLO, Rogério Licastro Torres de. Primeiros comentários ao novo código de processo civil. $1^{\mathrm{a}}$. Ed, São Paulo: RT. 2015. p. 2.147.
} 
Revista Eletrônica de Direito Processual - REDP.

Rio de Janeiro. Ano 13. Volume 20. Número 1. Janeiro a Abril de 2019

Periódico Quadrimestral da Pós-Graduação Stricto Sensu em Direito Processual da UERJ

Patrono: José Carlos Barbosa Moreira (in mem.). ISSN 1982-7636. pp. 532-566

www.redp.uerj.br

Não há ação rescisória sem uma decisão prolatada a ser impugnada. O art. 966 explicita que o objeto que circunda o mérito da ação é a existência de uma decisão, a impugnação versa, justamente, sobre a presença de um vício grave no ato decisório daquele processo transitado em julgado.

Não é toda e qualquer decisão que pode ser objeto de uma ação rescisória, necessita de um conteúdo que analise, em regra, o mérito da causa. Uma decisão sem adentrar no mérito, não há motivos para a proposição da ação rescisória, pela possibilidade de, em outro momento, em novo processo, discutir-se esse mesmo mérito.

No entanto, há a possibilidade de decisão sem o julgamento de mérito propiciar ação rescisória quando: mesmo sem julgar o mérito, impede a possibilidade de propositura de nova demanda, pela perempção ${ }^{9}$ ou quando inadmitir recurso correspondente ${ }^{10}$.

São essas as exceções, em todas as outras, há necessidade da decisão ter enfrentado o mérito.

No CPC/73, como já vimos, a palavra utilizada era sentença, o que definia somente uma espécie de um gênero maior de decisão. Mesmo com essa limitação, a interpretação sempre foi estendida aos acórdãos, por serem substituição natural da sentença. Já as decisões interlocutórias, em hipóteses excepcionais acima descritas, também podiam, ainda no ordenamento revogado, ser objeto de impugnação via ação rescisória, agora, no entanto, a situação é maior, seja pela manutenção de tal possibilidade, como em decisões interlocutórias de inadmissibilidade recursal ou

9 "De acordo com o art. 966, § 2.o, I, do CPC/2015, é rescindível "a decisão transitada em julgado que, embora não seja de mérito, impeça [...] I - nova propositura da demanda" (cf. também comentário supra). Assim, p. ex., a decisão que reconheça a ausência de legitimidade da parte, de acordo com a dicção legal, não resolve o mérito (cf. art. 485, VI, do CPC/2015), mas impede a repropositura da mesma de- manda (cf. art. 486, § 1.o, do CPC/2015), sendo, portanto, rescindível, ex vi do art. 966, § 2.o, I, do CPC/2015. Nota-se, aí, algo similar ao efeito negativo da coisa julgada que se opera quando proferida decisão de mérito.” MEDINA, José Miguel Garcia. Comentário ao art. 966. STRECK, Lenio. (3/2016). Comentários ao código de Processo Civil, $11^{a}$ edição.. [Minha Biblioteca]. Retirado de https://integrada.minhabiblioteca.com.br/\#/books/9788502635609/

10 "O art. 966, § 2.o, II, do CPC/2015 admite ação rescisória contra decisão que "embora não seja de méri- to, impeça [...] admissibilidade do recurso correspondente". Trata-se de figura mais restrita, que não se coloca em paralelo à referida no inciso anterior do mesmo parágrafo (cf. comentário su- pra). No caso referido no inciso II, deve-se estar diante de decisão que não admitiu recurso e que, com isso, gerou situação que impede a rediscussão do mérito (ou, em outras palavras, com a não admissão errônea do recurso surgiu a coisa julgada da decisão de mérito, ou o efeito negativo similar, quando decisão terminativa impedir a repropositura da ação)." MEDINA, José Miguel Garcia. Comentário ao art. 966. STRECK, Lenio. (3/2016). Comentários ao código de Processo Civil, $11^{a}$ edição.. [Minha Biblioteca]. Retirado de https://integrada.minhabiblioteca.com.br/\#/books/9788502635609/ 
Revista Eletrônica de Direito Processual - REDP.

Rio de Janeiro. Ano 13. Volume 20. Número 1. Janeiro a Abril de 2019

Periódico Quadrimestral da Pós-Graduação Stricto Sensu em Direito Processual da UERJ

Patrono: José Carlos Barbosa Moreira (in mem.). ISSN 1982-7636. pp. 532-566

www.redp.uerj.br

pelo fato da decisão interlocutória também ser objeto judicial que julga o mérito da demanda ou, ao menos, parte dele.

Essa hipótese da decisão sem mérito - sentença ou interlocutória - já detinha ampla aceitação pela doutrina e jurisprudência, com a admissão da ampliação do termo para decisão, no lugar de sentença, o que, no CPC/2015, ganha positivação adequada.

\subsubsection{Objeto rescindendo: decisão interlocutória, sentença, decisão monocrática ou acórdão}

O objeto da ação rescisória é uma decisão ${ }^{11}$ de mérito transitada em julgada.

Em regra, esse é o objeto que pode ser impugnado via ação rescisória. Saiu o termo sentença, da hipótese única de ação rescisória, como no CPC/73, para incluir decisão de mérito, pela amplitude maior do que a sentença. O termo decisão é bem mais correto, pelo fato de representar toda e qualquer espécie de decisão, seja ela sentença, decisão interlocutória de mérito, decisão monocrática ou um acórdão.

Todas essas são espécies do gênero decisã $o^{12}$, enquadrando perfeitamente no disposto no art. 966. Obviamente que uma sentença é totalmente possível de ser o objeto de ação rescisória, não impactando em nada tal alteração, contudo o intuito foi primar pela melhor representação da realidade processual, não restringindo somente a essa espécie o cabimento da rescisão. De modo consequente, se de uma sentença cabe recurso - a apelação, o julgamento deste será realizado, em regra, de modo colegiado, com uma decisão igualmente colegiada, o acórdão. Se o acórdão, em termos temporais ao processo, está posterior e acima da sentença, até pelo fato de ser a decisão que revisa a sentença, será, igualmente, cabível de rescisão.

A ampliação mesmo do termo para decisão representa a positivação da inclusão das interlocutórias e monocráticas.

\footnotetext{
11 "Chama a atenção, desde logo, a referência, no caput do art. 966, do cabimento da rescisória contra decisão de mérito (não mais a sentença, como consta do caput do art. 485 do CPC de 1973), o que significa, pertinentemente, que também as decisões interlocutórias de mérito, desde que transitadas materialmente em julgado, podem ser objeto de rescisão, além de sentenças e acórdãos.” BUENO, Cassio Scarpinella. Novo Código de Processo Civil anotado. São Paulo: Saraiva, 2015. p. 605.

12 Nesse sentido: "É cabível ação rescisória contra qualquer espécie de decisão de mérito, inclusive naquelas concernentes às decisões de jurisdição voluntária”. MARINONI, Luiz Guilherme. ARENHART, Sérgio Cruz. MITIDIERO, Daniel. Novo curso de processo civil. v. 3. São Paulo: RT, 2015. p. 592.
} 
Revista Eletrônica de Direito Processual - REDP.

Rio de Janeiro. Ano 13. Volume 20. Número 1. Janeiro a Abril de 2019

Periódico Quadrimestral da Pós-Graduação Stricto Sensu em Direito Processual da UERJ

Patrono: José Carlos Barbosa Moreira (in mem.). ISSN 1982-7636. pp. 532-566

www.redp.uerj.br

As decisões monocráticas ocorrem nas possibilidades do art. 932, devido ao enquadramento da situação processual em possibilidades autorizadoras de o relator julgar unipessoalmente, sem levar o recurso ou processo ao colegiado. São hipóteses excepcionais, geralmente com enquadramento em precedentes, seja para dar ou negar provimento.

Se essas decisões, proferidas somente pelo relator, são passíveis de ser a decisão final, caso nenhuma das partes intente com o agravo interno, logo, de certo modo, é uma decisão que faz as vezes de um acórdão, decidindo matéria que, a princípio, seria decidida pelo colegiado. Se a decisão monocrática pode ser a definidora da demanda, no mérito, pode, então, ser impugnada pela ação rescisória, sendo aquela a ser objeto da própria demanda.

A decisão interlocutória, a princípio, versa somente sobre situações incidentais, no transcurso da demanda, porém muitas vezes uma parte do mérito pode ser decidido dessa maneira, conforme dicção do art. 356, ensejando uma decisão interlocutória parcial de mérito.

Essa é uma decisão totalmente passível de ação rescisória para a impugnação, se houver vício na prolação. A doutrina ${ }^{13}$ e a jurisprudência ${ }^{14}$, mesmo no CPC/73, tinham

\footnotetext{
13 Outro ponto a ser observado a respeito do cabimento da ação rescisória se refere aos atos judiciais que através dela podem ser impugnados. Fala o caput do art. 485 do CPC em sentença de mérito. Ocorre que a palavra sentença está, aí, empregada em sentido bastante amplo, a querer significar provimento judicial. Deste modo, é perfeitamente possível o cabimento da ação rescisória contra acórdãos (e, aliás, pode-se mesmo arriscar dizer que é mais frequente - sic - a utilização da ação rescisória contra acórdãos que contra sentenças). E também contra decisões interlocutórias é cabível a ação rescisória, desde que esse provimento verse sobre o meritum causae. (...) Por esta razão é que parece mais adequado falar-se, na interpretação do caput do art. 485 , não em sentença, mas em provimento judicial. Sempre que se usar, pois, nesta obra, a palavra sentença, deve ser ela entendida em sentido amplo, para abranger também os demais provimentos judiciais (salvo quando expressamente indicado de forma diversa). CÂMARA, Alexandre Freitas. Ação rescisória. Rio de Janeiro: Lumen Juris, 2007. p. 55/56. "Até mesmo as decisões interlocutórias são passíveis de impugnação por meio de ação rescisória, ainda que excepcionalmente. Basta imaginar a hipótese de o juiz de primeiro grau pronunciar a decadência ou a prescrição, alcançando apenas um dos litisconsortes ativos. Como o processo segue em razão da ação remanescente relativa ao outro litisconsorte, tem-se que o pronunciamento jurisdicional é mera decisão interlocutória, apesar de ter versado sobre matéria de mérito." SOUZA, Bernardo Pimentel. Introdução aos recursos cíveis e à ação rescisória. $3^{\mathrm{a}}$ ed., São Paulo: Saraiva, 2004. p. 724. "Como esses pronunciamentos judiciais deveriam vir sempre em uma sentença, então falou ele em sentenças de mérito; mas, surgindo na experiência concreta uma decisão atípica, como essa aqui examinada, prevalece a substância do preceito ditado em lei e não as formas de sua expressão verbal. (..) Mas a decisão interlocutória que solucionar o mérito, (..), será uma decisão de mérito e como tal deve ser tratada. Ser interlocutória significa somente ser proferida no curso do processo, sem pôr fim à fase cognitiva nem determinar o exaurimento do procedimento em primeiro grau jurisdicional; não significa não ser de mérito, embora o legislador não houvesse cogitado de decisões interlocutórias de mérito" DINAMARCO, Cândido Rangel. Nova era do processo civil. $2^{\mathrm{a}}$ ed. São Paulo: Malheiros, 2007. p. 291/292.
} 
Revista Eletrônica de Direito Processual - REDP.

Rio de Janeiro. Ano 13. Volume 20. Número 1. Janeiro a Abril de 2019

Periódico Quadrimestral da Pós-Graduação Stricto Sensu em Direito Processual da UERJ

Patrono: José Carlos Barbosa Moreira (in mem.). ISSN 1982-7636. pp. 532-566

www.redp.uerj.br

posicionamento pela possibilidade de ação rescisória quando uma decisão interlocutória transitada em julgado decidisse questão de mérito ${ }^{15}$, como ampliação de utilização do termo sentença.

No entanto, a alteração constante no art. 966 positiva uma abertura maior no cabimento, com a retirada de dúvidas sobre as espécies de decisões passíveis da rescisória, elencando, claramente, o cabimento em decisão interlocutória, seguindo a tendência jurisprudencial.

Em qualquer das espécies de decisões acima dispostas, há a necessidade de ser uma decisão transitada em julgado, o que, de modo contrário, não haveria motivos para a demanda rescisória, podendo a parte prejudicada, ainda, interpor um recurso. Somente com a impossibilidade de anulação ou modificação, via recurso, que o cabimento da ação rescisória nasce. Afinal, qual seria o motivo de se intentar uma demanda para rescindir, se a parte, ainda, poderia recorrer? Por isso, é necessário pressuposto para a interposição da ação, o trânsito em julgado da decisão - qualquer que seja sua espécie.

$14 \quad$ RECURSO ESPECIAL N $\mathbf{N}^{\mathbf{0}} \mathbf{7 1 1 . 7 9 4}$ - SP (2004/0179322-2) RELATORA : MINISTRA NANCY ANDRIGHI RECORRENTE: JUVENAL CAMPOS DE AZEVEDO CANTO ADVOGADOS: JOAQUIM JAIR XIMENES AGUIAR E OUTROS - PEDRO DA SILVA DINAMARCO E OUTROS RECORRIDO : MASSA FALIDA DE NOVAURBE S/A COMÉRCIO ECONSTRUÇÃO E OUTROS REPR.POR : JUVENAL CAMPOS DE AZEVEDO CANTO - SÍNDICO EMENTA Processo civil. Recurso especial. Acórdão proferido em agravo interno, interposto contra decisão unipessoal que havia indeferido a petição inicial de ação rescisória. Redação sucinta, com remissão integral às razões da decisão agravada. Possibilidade de interposição de recurso especial diretamente para a impugnação do mérito do julgado, sem necessidade de arguição de nulidade do decisum. Ação rescisória. Propositura visando à impugnação de acórdão lavrado em sede de agravo de instrumento. Possibilidade, caso a decisão recorrida tenha decidido questão de mérito, com autoridade de coisa julgada. - A $3^{\mathrm{a}}$ e a $4^{\mathrm{a}}$ Turma do STJ já firmaram seu entendimento, em diversos precedentes, no sentido de que é lícita a remissão, promovida pelo acórdão recorrido, aos fundamentos da decisão impugnada, sem necessidade de repeti-los. - A ação rescisória pode ser utilizada para a impugnação de decisões com conteúdo de mérito e que tenham adquirido a autoridade da coisa julgada material. Em que pese incomum, é possível que tais decisões sejam proferidas incidentalmente no processo, antes da sentença. Isso pode ocorrer em três hipóteses: (i) em diplomas anteriores ao CPC/73; (ii) nos processos regulados pelo CPC em que, por algum motivo, um dos capítulos da sentença a respeito do mérito é antecipadamente decidido, de maneira definitiva; e, finalmente (iii) sempre que surja uma pretensão e um direito independentes do direito em causa, para serem decididos no curso do processo. Exemplo desta última hipótese é a definição dos honorários dos peritos judiciais e do síndico na falência: o direito à remuneração desses profissionais nasce de forma autônoma no curso do feito, e no próprio processo é decidido, em caráter definitivo. Não há por que negar a via da ação rescisória para impugnar tal decisão. Recurso especial conhecido e provido. ACÓRDÃO Vistos, relatados e discutidos estes autos, acordam os Ministros da TERCEIRA TURMA do Superior Tribunal de Justiça, na conformidade dos votos e das notas taquigráficas constantes dos autos, por unanimidade, conhecer do recurso especial e dar-lhe provimento, nos termos do voto da Sra. Ministra Relatora. Os Srs. Ministros Castro Filho, Humberto Gomes de Barros, Ari Pargendler e Carlos Alberto Menezes Direito votaram com a Sra. Ministra Relatora. Brasília (DF), 5 de outubro de 2006 (data do julgamento). MINISTRA NANCY ANDRIGHI Relatora.

15 Enunciado n. ${ }^{\circ} 336$ do FPPC: Cabe ação rescisória contra decisão interlocutória de mérito. 
Revista Eletrônica de Direito Processual - REDP.

Rio de Janeiro. Ano 13. Volume 20. Número 1. Janeiro a Abril de 2019

Periódico Quadrimestral da Pós-Graduação Stricto Sensu em Direito Processual da UERJ

Patrono: José Carlos Barbosa Moreira (in mem.). ISSN 1982-7636. pp. 532-566

www.redp.uerj.br

Além do devido trânsito em julgado, existe a necessidade da decisão ter enfrentado o mérito, o que, consequencialmente, ocasiona a impossibilidade de proposição de nova ação para discutir a matéria. Uma sentença definitiva quando transformadas em coisa julgada material, mediante a não interposição ou não cabimento de recurso, impede outra demanda de discutir novamente o mérito e, por isso, nasce a necessidade, se houver vício, da rescisão do conteúdo da sentença, via ação rescisória.

\subsubsection{Objeto rescindendo sem mérito: exceções de cabimento da ação rescisória}

A regra, como vimos, é o cabimento da rescisória somente das decisões de mérito, qualquer que seja a forma dessa decisão.

No entanto, outras decisões, ainda que sem mérito ${ }^{16}$, também serão cabíveis de serem objeto da ação rescisória, excepcionalizando a própria conceituação do instituto rescisório.

De modo geral, uma decisão sem mérito impossibilita o cabimento da ação rescisória pela própria inutilidade da relação entre os institutos. Quando o juízo prolata a decisão sem enfrentamento do mérito, põe fim ao processo - ou parte dele, por algum vício processual, não respondendo no processo os pedidos pleiteados na inicial. A razão pela qual o autor foi a juízo continua sem o provimento jurisdicional, com a possibilidade de buscar novamente o Judiciário para a solução do seu conflito de interesses. Se o autor, numa ação com decisão sem julgamento de mérito, pode entrar com outra ação sobre a mesma matéria, qual motivo levaria a ter interesse de agir para rescindir uma decisão dessa transitada em julgado? A princípio, nenhum interesse, o que leva ao descabimento da rescisória, dada a total possibilidade da parte deve intentar nova demanda sobre a mesma causa de pedir.

As exceções trazidas pelo CPC/2015 estão elencadas no art. $988, \S 2^{\circ}$, na maioria das vezes, quando o trânsito em julgado dessa decisão, ainda que sem mérito, impeça duas

\footnotetext{
16 "Levando em conta estas situações apresentadas e outras práticas, o NCPC passa a admitir o cabimento de rescisória em decisões transitadas em julgado que, mesmo não sendo de mérito, impedem a repropositura da demanda ou a admissibilidade do recurso correspondente(art. 966, §2º." ARAÚJO, José Henrique Mouta. Decisão rescindível e o novo CPC: aspectos polêmicos e atuais. Revista Jurídica Lusobrasileira, v. 4, p. 683-708, 2015. p. 697.
} 
Revista Eletrônica de Direito Processual - REDP.

Rio de Janeiro. Ano 13. Volume 20. Número 1. Janeiro a Abril de 2019

Periódico Quadrimestral da Pós-Graduação Stricto Sensu em Direito Processual da UERJ

Patrono: José Carlos Barbosa Moreira (in mem.). ISSN 1982-7636. pp. 532-566

www.redp.uerj.br

situações: a propositura de uma nova ação e a admissibilidade de um recurso correspondente.

A primeira hipótese ocorre quando o autor intenta uma mesma demanda - mesma causa de pedir e partes - pela terceira vez, com as duas outras anteriores julgadas extintas sem julgamento do mérito. Caso o mesmo aconteça na terceira demanda, ocorre o fenômeno da perempção, com a perda do direito de intentar novamente tal ação. A sentença, ou decisão, nessa hipótese, continua a ser sem mérito, porém impede a proposição de uma nova ação. Se o autor, que intentou a mesma demanda por três vezes, enquadrar a decisão ou sentença sem mérito da última em alguma dessas possibilidades descritas nos incisos do art. 966, cabível será a ação rescisória, com o intuito de anular a decisão sem mérito que contém um vício, retirando, consequencialmente, essa impossibilidade de proposição da demanda, permitindo ao autor, por intermédio da rescisória, rediscutir o objeto do conflito de interesses que estava impossibilitada pela perempção.

Essa possibilidade enquadra-se nas exceções, justamente por conter um vício na condução do processo ou prolação da decisão/sentença e, mesmo sem mérito, atinge o direito do autor e, este não pode mais, pela ocorrência da perempção, de pleitear a prestação jurisdicional daquela demanda novamente.

Em síntese, em decisão sem mérito que importe em perempção, a ação rescisória é cabível.

$\mathrm{Na}$ segunda hipótese, se a decisão não for de mérito, porém inadmite a admissibilidade de recurso correspondente, contendo um vício, incorrendo no trânsito em julgado indevido, pode, da mesma maneira, ser fruto de ação rescisória, com o intuito de preservar o direito de recorrer.

O vício necessário, delimitado pelo art. 966, necessariamente, deve constar nessa decisão que impede a admissibilidade do recurso interposto, não em outra decisão daquela demanda, mesmo que anterior.

Se o recurso correto foi interposto e foi inadmitido com uma decisão, pelo não conhecimento ou prosseguimento do recurso, de modo viciado, com algumas das hipóteses que possibilitam a rescisória, esta será cabível para rescindir essa decisão, com o devido prosseguimento do julgamento da matéria daquele recurso que foi injusta e incorretamente não conhecido. 
Revista Eletrônica de Direito Processual - REDP.

Rio de Janeiro. Ano 13. Volume 20. Número 1. Janeiro a Abril de 2019

Periódico Quadrimestral da Pós-Graduação Stricto Sensu em Direito Processual da UERJ

Patrono: José Carlos Barbosa Moreira (in mem.). ISSN 1982-7636. pp. 532-566

www.redp.uerj.br

A decisão viciada, ainda que sem ser dotada de mérito, impediu que a parte tivesse a resposta jurisdicional sobre o seu recurso. Constatada a ocorrência do vício e o enquadramento correto dos pressupostos da rescisória, mesmo não contendo matéria de mérito, é totalmente rescindível decisão viciada que inadmitiu tal recurso.

Uma dúvida pertinente está no cabimento da ação rescisória sobre uma decisão ou sentença sem mérito, mas sobre o capítulo da decisão que condena o autor ao pagamento de honorários. $\mathrm{O}$ intuito, dada a existência de um vício nessa decisão, é rescindir o conteúdo condenatório em honorários advocatícios, uma vez que mesmo a decisão não contendo mérito, o capítulo sobre honorários é um conteúdo de mérito, sendo, portanto, totalmente rescindível.

A rescisão seria limitada ao conteúdo de mérito inserido dentro de uma decisão sem mérito viciada, ou seja, a condenação em honorários advocatícios.

Outra decisão cabível da ação rescisória é a sentença que extingue a execução, colocando fim ao processo, encerrando a prestação jurisdicional, contudo sem conter um mérito, pelo fato do próprio processo executivo não proporcionar um juízo meritório, mas somente uma busca pela satisfação e efetividade do direito existente a ser executado. Uma busca pela satisfação específica do direito, sem um mérito a ser julgado.

No entanto, mesmo sem mérito, não pode ser classificada como uma decisão idêntica àquela sem mérito do processo de conhecimento, até pelo fato de uma execução ter a possibilidade de uma decisão desses moldes, quando a inicial - na execução de título extrajudicial - ou a petição do art. 524 - cumprimento de sentença - for indeferida ou, ainda, quando houver desistência. Nessas decisões, ainda que encerrando a execução, não cabe a rescisória, por ser plenamente possível do exequente pleitear, novamente, nova demanda de execução.

Por outro lado, nas decisões que extinguem a execução ou que reconhecem a prescrição ou decadência, há a possibilidade de cabimento da ação rescisória.

\subsubsection{Coisa julgada e, em regra, material}

Para configurar a possibilidade de uma ação rescisória, há a necessidade da formação da coisa julgada, com o devido trânsito em julgado de decisão. Se a decisão que se almeja impugnar não transitou em julgado, não há motivos para proposição da ação rescisória. 
Revista Eletrônica de Direito Processual - REDP.

Rio de Janeiro. Ano 13. Volume 20. Número 1. Janeiro a Abril de 2019

Periódico Quadrimestral da Pós-Graduação Stricto Sensu em Direito Processual da UERJ

Patrono: José Carlos Barbosa Moreira (in mem.). ISSN 1982-7636. pp. 532-566

www.redp.uerj.br

A medida rescisória é exceção ${ }^{17}$, somente em algumas hipóteses, para possibilitar a rediscussão de matéria já definida, já alcançada pela imutabilidade. Se inexistir o trânsito em julgado, existe, então, o prazo para a interposição de recurso, remédio cabível para conseguir, sobre aquela decisão prolatada na demanda, as alterações, modificações ou anulações pertinentes no processo.

Somente com a ausência de possibilidade recursal - seja pelo não cabimento recursal ou pela fluência do prazo sem o mesmo, com a formação da coisa julgada, caberá a revisão de tal ato e a sua possibilidade de rescindibilidade, via ação rescisória.

O intuito de existência da ação rescisória é desfazer a imutabilidade configurada pelo trânsito em julgado, visando anular a decisão que, mesmo transitada em julgado, contenha vício grave que atente à segurança jurídica.

A decisão impugnável pela ação rescisória deve ter enfrentado o mérito, formando com o seu trânsito em julgado, uma coisa julgada material. A busca pela rescisão da decisão com certa imutabilidade somente é permissível pela impossibilidade de alteração do conteúdo, via recurso.

Para a formação dessa coisa julgada material, não há a necessidade de esgotamento de todos os recursos, mesmo diante de uma sentença em que a parte não interpôs a apelação, por sua própria escolha, transitando em julgado, com a formação da coisa julgada material, posteriormente, com a descoberta de um vício, cabe ação rescisória, de forma totalmente independente sobre a quantidade de recursos interpostos ou não, conforme sumulado pelo $\mathrm{STF}^{18}$.

Pelo princípio da primazia ao julgamento de mérito, a parte pode intentar demanda rescisória sem o trânsito em julgado e, durante a tramitação este ocorrer, gerando validade à demanda? Depende de quando ocorrer o trânsito em julgado e da decisão inicial sobre a demanda, pelo relator. Se este último, ao receber a ação rescisória, analisa, desde logo, o recebimento da inicial e, constatando tal ausência de trânsito em julgado, pode, de plano,

\footnotetext{
17 “O recrudescimento da decisão judicial, ápice do discurso jurídico, é imprescindível para que o próprio discurso tenha razão de ser, e, assim, realmente exista enquanto discurso jurídico. A coisa julgada, portanto, não é uma regra preocupada com o conteúdo do discurso, mas sim uma condição para que o discurso seja um discurso institucional limitado no tempo e, destarte, um discurso jurídico propriamente dito. $\mathrm{Na}$ verdade, se a discussão jurídica não tiver um termo a partir do qual a decisão não possa ser questionada, não haverá sentido em falar em discurso jurídico nem muito menos em realizá-lo." MARINONI, Luiz Guilherme. Coisa Julgada Inconstitucional. 2a.. ed. São Paulo: Revista dos Tribunais, 2010. p. 56/57.

18 Súmula 514 STF. Admite-se ação rescisória contra sentença transitada em julgado, ainda que contra ela não se tenha esgotado todos os recursos.
} 
Revista Eletrônica de Direito Processual - REDP.

Rio de Janeiro. Ano 13. Volume 20. Número 1. Janeiro a Abril de 2019

Periódico Quadrimestral da Pós-Graduação Stricto Sensu em Direito Processual da UERJ

Patrono: José Carlos Barbosa Moreira (in mem.). ISSN 1982-7636. pp. 532-566

www.redp.uerj.br

indeferir a inicial, com a possibilidade, no entanto, de que a parte proponha nova ação rescisória.

Por outro lado, se o relator verificar que entre a proposição da ação rescisória e a sua decisão, o trânsito em julgado tiver ocorrido, mesmo diante de um vício, há possibilidade de aceitação do que seria essa ação rescisória prematura ${ }^{19}$.

\subsubsection{A existência de vícios na decisão impugnada: hipóteses do art. 966}

A possibilidade de rescindir uma decisão de mérito transitada em julgado tem natureza excepcional, não se tornando corriqueiro, somente com a conjunção de pressupostos. Um desses requisitos está na existência, na decisão impugnada, de um vício, previsto em lei, passível de causar a rescindibilidade ${ }^{20}$ da coisa julgada material.

$\mathrm{O}$ art. 966 estipula um rol restritivo ${ }^{21}$ de hipóteses de vícios graves que permitem a relativização da coisa julgada material pela configuração de uma dessas situações. Um vício constante nesse rol é considerado como um atentado à segurança jurídica, ao permitir que a decisão continue a produzir efeitos, com total eficácia, abrindo a brecha para anular e expurgar essa decisão viciada do ordenamento jurídico, constando tal irregularidade e proferindo uma decisão válida, sem máculas.

Não há a possibilidade de analogia ou utilização de outras espécies de vícios para invalidar uma decisão de mérito transitada em julgado. O CPC/2015 limita as

\footnotetext{
19 "Para que se ajuíze a ação rescisória, é preciso que haja trânsito em julgado. Imagine-se, porém, que a ação rescisória seja ajuizada antes do trânsito em julgado da decisão rescindenda (ação rescisório prematura). O caso é de indeferimento da petição inicial. Não sendo a petição inicial indeferida, mas sobrevindo o trânsito em julgado na pendência do processo rescisório, o defeito será suprido, impedindo a extinção do processo sem exame do mérito por esse motivo. Nesse caso, a ação rescisória, quando proposta, era inadmissível, mas um fato superveniente tornou-a admissível. O tribunal, em razão do disposto no art. 493 do CPC, deve levar em conta os fatos supervenientes. E, como se sabe, o art. 493 aplica-se em qualquer grau de jurisdição, ${ }^{\circ}$, sendo certo que os "fatos supervenientes, a serem considerados pelo juiz no momento da sentença tanto podem dizer respeito ao juízo de admissibilidade como ao próprio mérito"." CUNHA, Leonardo José Carneiro da; DIDIER JR., Fredie. Curso de direito processual civil. Meios de impugnação às decisões judiciais e processo nos tribunais. 13ª ed. Salvador: Jus Podivm, 2016. p. 441.

20 "A rescindibilidade é um vício processual bastante específico, eis que somente surge após o advento da coisa julgada material e apenas pode ser pronunciada no bojo de uma ação rescisória. Essas rescindibilidades (art. 966) são aquelas situações em que é permitido o uso da ação rescisória que, por sua vez, busca justamente reconhecer um vício processual de extrema gravidade, que até mesmo pode contaminar o processo e a decisão de mérito nele proferida." HARTMANN, Rodolfo Kronemberg. Curso Completo do Novo Processo Civil. 4ª . ed. Niterói: Editora Impetus, 2016. p. 692.

21 "O cabimento da ação rescisória limita-se a casos extraordinários, expressamente enumerados em lei”. MARINONI, Luiz Guilherme. ARENHART, Sérgio Cruz. MITIDIERO, Daniel. Novo curso de processo civil. v. 2. São Paulo: RT, 2015. p. 588.
} 
Revista Eletrônica de Direito Processual - REDP.

Rio de Janeiro. Ano 13. Volume 20. Número 1. Janeiro a Abril de 2019

Periódico Quadrimestral da Pós-Graduação Stricto Sensu em Direito Processual da UERJ

Patrono: José Carlos Barbosa Moreira (in mem.). ISSN 1982-7636. pp. 532-566

www.redp.uerj.br

possibilidades que reputa como graves, com tamanha força, que são passíveis de relativizar a coisa julgada. Um outro vício que a parte considere grave, mas que não esteja no rol do art. 966, não permite a utilização da ação rescisória para fins de anulação da decisão.

Situações como crimes do juiz, incompetência absoluta, juiz impedido, comprovação de prova falsa, erro de fato, dentre outros. São diversas hipóteses que possibilitam a ação rescisória, devendo o autor, na inicial, indicar qual das situações entende como presente que resulte na ação rescisória.

Não há óbice para que o autor indique na mesma rescisória, dois ou mais motivos ensejadores de tal demanda na mesma decisão. De modo inverso, sem nenhuma das hipóteses do art. 966, não cabe ação rescisória. Se, ainda assim, interpor ação por outro vício não ali constante, por mais grave que esse seja, o resultado deve ser o indeferimento da inicial ou a improcedência do pedido.

\subsubsection{Prazo para interposição ou proposição}

Para a interposição ou proposição da ação rescisória, a parte interessada tem de cumprir todos os pressupostos e intentar a demanda, dentro do prazo de dois anos, a contar da data do trânsito em julgado da decisão, que se almeja impugnar ${ }^{22}$, conforme disposto no art. 975.

O prazo é decadencial, não sujeito a qualquer hipótese de suspensão ou interrupção. O intuito da ação rescisória passa pela possibilidade de anular uma decisão de mérito transitada em julgado, com a incidência de um vício grave, porém não pode essa brecha para a relativização da coisa julgada permanecer aberta por um grande período de tempo. Há de se permitir a rescisão da coisa julgada pela existência do vício, contudo há de se preservar a segurança jurídica após certo tempo.

\footnotetext{
22 "O prazo para propor a ação rescisória começa a fluir sempre e unicamente do trânsito em julgado da última decisão proferida no processo, ainda quando algum dos capítulos sentenciais se haja tornado irrecorrível antes. Se uma sentença ou acórdão contiver dois ou mais capítulos, sendo objeto de recurso somente um deles, aquele prazo começará, em relação a todos os capítulos, quando passar em julgado o acórdão julgador desse recurso. Essa firme orientação, que conta com o apoio do disposto nos arts. 467 e 485, caput, do Código de Processo Civil, desconsidera a teoria dos capítulos de sentença para impedir que no processo se implantem situações de incerteza que pudessem constituir fator de insegurança jurídica para as partes". DINAMARCO, Cândido Rangel. Capítulos de sentença. 4. ed. São Paulo: Malheiros, 2009. p. 123.
} 
Revista Eletrônica de Direito Processual - REDP.

Rio de Janeiro. Ano 13. Volume 20. Número 1. Janeiro a Abril de 2019

Periódico Quadrimestral da Pós-Graduação Stricto Sensu em Direito Processual da UERJ

Patrono: José Carlos Barbosa Moreira (in mem.). ISSN 1982-7636. pp. 532-566

www.redp.uerj.br

Não existem meios de possibilitar eternamente a correção de um vício, por mais grave que for um vício, em algum momento, a decisão, outrora viciada, deve revestir-se de imutabilidade absoluta, impossibilitando a ação rescisória ${ }^{23}$.

Se a ação rescisória for interposta em prazo posterior ao de dois anos após o trânsito em julgado, não cumpre este pressuposto. Entretanto, há a exceção do término do prazo dos dois anos cair em dia não útil, possibilitando a prorrogação para o primeiro dia útil. A jurisprudência tinha pacificação sobre a questão ${ }^{24}$, nessa feita, o art. $975, \S^{\circ}$ somente positivou o entendimento jurisprudencial, prorrogando ao primeiro dia em que houver expediente forense, para fins de contagem do prazo para a ação rescisória.

Essa é a regra geral de contagem de prazo para a ação rescisória: dois anos a partir do trânsito em julgado.

No entanto, diversas exceções são visíveis e enfrentaremos cada ponto.

A primeira consideração a ser realizada será na existência de várias decisões na demanda a serem rescindíveis, o que se denomina de coisa julgada progressiva, como já vimos. Na existência de uma decisão interlocutória de mérito, há de se esperar a decisão proferida na sentença, também de mérito, para a prolação da decisão? Esse é o entendimento que dá para retirar-se do art. 975, quando dispõe sobre os dois anos contados do trânsito em julgado da última decisão proferida no processo.

O que seria essa última decisão do processo? Esse ponto é importante, contudo, antes desse desenrolar, necessita-se diferenciar as coisas julgadas progressivas em dois pontos: aquelas decisões interlocutórias e sentenças proferidas em momentos diferentes; e, também, a prolação de uma só sentença, mas com diversos capítulos, com impugnação, via recurso, somente de modo parcial, criando, materialmente, trânsitos em julgado diversos.

Para a primeira hipótese de coisa julgada progressiva, temos o entendimento de que a decisão parcial de mérito ensejaria uma nova demanda, como uma desacumulação da

23 Enunciado n. 341 do FPPC: O prazo para ajuizamento de ação rescisória é estabelecido pela data do trânsito em julgado da decisão rescindenda, de modo que não se aplicam as regras dos $\S \S 2^{\circ}$ e $3^{\circ}$ do art. 975 do CPC à coisa julgada constituída antes de sua vigência.

24 "PROCESSUAL CIVIL. AÇÃO RESCISÓRIA. TERMO INICIAL DO PRAZO DE DOISANOS. RECURSO CONSIDERADO INEXISTENTE. TRÂNSITO EM JULGADO DADECISÃO QUE APRECIOU O ÚLTIMO RECURSO INTERPOSTO. SÚMULA 401/STJ. PRAZO DECADENCIAL. TÉRMINO EM DIA NÃO-ÚTIL. PRORROGAÇÃO. PRIMEIRODIA ÚTIL SEGUINTE. PRECEDENTE DA CORTE ESPECIAL.AGRAVO REGIMENTAL A QUE SE NEGA PROVIMENTO. (STJ - AgRg no REsp: 1231666 BA 2011/0012811-8, Relator: Ministro TEORI ALBINO ZAVASCKI, Data de Julgamento: 17/04/2012, T1 - PRIMEIRA TURMA, Data de Publicação: DJe 24/04/2012) 
Revista Eletrônica de Direito Processual - REDP.

Rio de Janeiro. Ano 13. Volume 20. Número 1. Janeiro a Abril de 2019

Periódico Quadrimestral da Pós-Graduação Stricto Sensu em Direito Processual da UERJ

Patrono: José Carlos Barbosa Moreira (in mem.). ISSN 1982-7636. pp. 532-566

www.redp.uerj.br

demanda, importando em uma bipartição processual e cognitiva, com, agora, duas ou mais demandas no lugar daquela inicial que cumulava diversas. Diante desse pensamento, não há dúvidas sobre o cabimento da ação rescisória sobre a decisão parcial de mérito e, ainda, com a visão de que o prazo começa a contar logo após o seu próprio trânsito em julgado.

Na segunda hipótese, sobre a coisa julgada de capítulos da sentença, a regra será a literalidade do art. 975, contando, naquela mesma demanda, somente do trânsito em julgado da última questão e decisão a ser proferida. Ou seja, se uma sentença for prolatada em 2017, mesmo o conteúdo dessa não recorrido, com o devido trânsito em julgado parcial, não será possível o intento da ação rescisória, ainda, contando, para tanto, após o último julgamento do último recurso.

Outro ponto a se considerar como excepcional sobre a contagem de prazo da ação rescisória, depende do vício a ser impugnado, gerando três hipóteses de contagens diversas da regra, como exceções para contagens diferentes, conforme o art. $975, \S 2^{\circ}$ e $\S 3^{\circ}$ : descoberta de prova nova; baseada em simulação ou colusão; e, ainda, hipótese da coisa julgada inconstitucional.

Na hipótese da existência do vício da descoberta de prova nova, o prazo permanece de dois anos para a interposição ou proposição da ação rescisória, modificando-se somente o início, não sendo mais da data do trânsito em julgado, mas da descoberta da prova nova. Não há, contudo, como ter ciência de quando a parte interessada descobrirá a prova nova, não podendo deixar essa possibilidade aberta eternamente, fixando o prazo de cinco anos para realizar a descoberta e intentar a demanda, iniciando a contagem da mesma forma da data do trânsito em julgado.

São dois prazos a serem cumpridos quando da alegação de descoberta da prova nova: o prazo de dois anos após a descoberta; e o prazo de cinco anos do trânsito em julgado.

O autor da ação rescisória deve preocupar-se com a conjunção dos dois prazos, ou seja, que seja descoberta em, no máximo, cinco anos do trânsito em julgado e, a partir da descoberta, deve cumprir o prazo de dois anos para a proposição da demanda.

Importante, ainda, salientar que o autor deve comprovar a data de tal descoberta, talvez o mais difícil a ser realizar na demanda, mas essencial para tal cumprimento.

A outra exceção acontece na hipótese de ação rescisória baseada em simulação ou colusão entre as partes, o prazo para o terceiro prejudicado ou o Ministério Público, 
Revista Eletrônica de Direito Processual - REDP.

Rio de Janeiro. Ano 13. Volume 20. Número 1. Janeiro a Abril de 2019

Periódico Quadrimestral da Pós-Graduação Stricto Sensu em Direito Processual da UERJ

Patrono: José Carlos Barbosa Moreira (in mem.). ISSN 1982-7636. pp. 532-566

www.redp.uerj.br

continua o mesmo de dois anos, modificada a forma de início da contagem, desvinculada do trânsito em julgado e contando a partir da ciência de que houve simulação ou colusão.

Percebe-se que tal hipótese não trabalha com limite para tal descoberta, somente com o início do prazo decadencial de dois anos a partir desse momento. De mesmo modo, o autor da ação rescisória deve comprovar a ciência da simulação ou colusão, para fins de contagem do prazo.

Apesar de não estar disposta no art. 975 e seus parágrafos, outra contagem de prazo para a interposição da ação rescisória existe, na hipótese da coisa julgada inconstitucional. A diferença quanto a regra geral da contagem de prazo não passa pela quantidade desse, mas pela forma de início. De maneira diferente, o art. 525, $\S 15$ estipula que inicia-se a contagem a partir do trânsito em julgado da decisão do STF que julgou a norma basilar da decisão atacada na rescisória como inconstitucional.

Atente-se à mudança: o prazo começa a partir do trânsito em julgado da decisão paradigma, do STF, sobre a inconstitucionalidade.

É, portanto, um modo sui generis de contagem de prazo de ação rescisória.

Dessa feita, o prazo da rescisória continua por dois anos, contudo altera-se o início de sua contagem, como uma possibilidade imensa, dependendo do controle de constitucionalidade posterior, com o resultado pela inconstitucionalidade da norma utilizada na decisão que se quer rescindir ${ }^{25}$.

Há uma outra hipótese de contagem diversa do prazo para a proposição da ação rescisória, isso sobre as decisões sobre processos sobre transferência de terras públicas rurais, o que, mediante o previsto no art. $8^{\circ} \mathrm{C}$ da Lei $\mathrm{n}^{\circ} 6.739 / 79$, será de oito anos tal prazo.

\subsection{Legitimidade da ação rescisória}

\footnotetext{
25 "Trata-se de mais uma hipótese em que o termo inicial do prazo de 2 (dois) anos para a propositura da rescisória é contado não do trânsito em julgado da decisão rescindenda, sim de marco posterior a ele, no caso do trânsito em julgado da decisão do STF que declara a inconstitucionalidade de lei ou a considera incompatível com a Constituição Federal.” MAZZEI, Rodrigo; GONÇALVES, Tiago Figueiredo. Primeiras linhas sobre a disciplina da ação rescisória no CPC/15. Coleção Novo CPC - Doutrina Selecionada - v.6 Processo nos Tribunais e Meios de Impugnação às Decisões Judiciais. Orgs: DIDIER JR., Fredie; FREIRE, Alexandre; MACEDO, Lucas Buril de; PEIXOTO, Ravi. Salvador: JusPodivm, 2015. p. 201.
} 
Revista Eletrônica de Direito Processual - REDP.

Rio de Janeiro. Ano 13. Volume 20. Número 1. Janeiro a Abril de 2019

Periódico Quadrimestral da Pós-Graduação Stricto Sensu em Direito Processual da UERJ

Patrono: José Carlos Barbosa Moreira (in mem.). ISSN 1982-7636. pp. 532-566

www.redp.uerj.br

Para a ação rescisória ser intentada, necessária é verificação da legitimidade para tais pontos, com a possibilidade de ser parte autora ou ré nessa demanda rescisória.

Os legitimados ativos para a proposição da ação rescisória estão especificados no art. 967 e veremos a seguir sobre as suas possibilidades e requisitos. O CPC/2015, no capítulo específico da ação rescisória, não dispõe sobre a legitimidade passiva, com a necessidade de seguir a regra geral de tal matéria.

\subsubsection{Legitimidade ativa da ação rescisória}

Para a proposição de ação rescisória deve-se observar a legitimidade para tal ato, o que o art. 967 já preconiza, ao dispor sobre os legítimos para tanto: quem foi parte no processo ou o seu sucessor a título universal ou singular; o terceiro juridicamente interessado; o Ministério Público.

A primeira é a mais óbvia, ou seja, quem foi parte na demanda anterior pode, evidentemente, propor a ação rescisória, pelo fato de que sofre os efeitos e a eficácia daquela decisão transitada em julgado. No entanto, não será qualquer das partes que poderá propor tal demanda, com a necessidade da comprovação de prejuízo com aquela decisão a ser rescindida. Sem o prejuízo comprovado, não há o interesse de agir.

Dessa feita, quem não foi prejudicado pela decisão de mérito transitada em julgado, não tem motivos para pleitear a rescisão.

O vencedor no processo originário tem legitimidade para tanto? Como não há prejuízo para aquela parte na demanda, dado a eficácia da decisão, não há, de igual modo, legitimidade para tanto, pelo vencedor. De modo inverso, a parte vencida tem tal legitimidade para tal intento.

No mesmo viés, o terceiro prejudicado também é legítimo para pleitear a rescisão daquela decisão que lhe impacta de modo negativo, a qual entender que existe um vício, contudo, para tal desiderato ser possível, deve demonstrar a relação com a demanda, dado o impacto que o ato decisório e, ainda que este seja de modo negativo, a lhe trazer, portanto, um prejuízo, seja processual ou material.

Não basta somente a relação, o vínculo do terceiro ao processo, a decisão transitada em julgado deve causar-lhe um prejuízo, um efeito negativo em sua situação jurídica, para, a partir daí, pleitear a rescisão daquela decisão. 
Revista Eletrônica de Direito Processual - REDP.

Rio de Janeiro. Ano 13. Volume 20. Número 1. Janeiro a Abril de 2019

Periódico Quadrimestral da Pós-Graduação Stricto Sensu em Direito Processual da UERJ

Patrono: José Carlos Barbosa Moreira (in mem.). ISSN 1982-7636. pp. 532-566

www.redp.uerj.br

O Ministério Público ${ }^{26}$ é legítimo para intentar ação rescisória, contudo em hipóteses específicas, delineadas no próprio art. 967, III: em processos que não foi ouvido, mas que havia obrigação de sê-lo; quando ou vício da decisão for simulação ou colusão; nas outras possibilidades em que a lei impõe sua participação, na forma de fiscal da norma jurídica.

O Ministério Público não tem a necessidade de comprovar o prejuízo para a presença do interesse de agir, pela estipulação legal de sua legitimidade. Não é possível, tampouco faz sentido que seja o prejudicado, mas sim a própria sociedade, como um todo. Especificadamente, o Ministério Público pode intentar demanda rescisória em demandas que deveria ser ouvido e não foi, o que cria, além da legitimidade para tal, uma nova hipótese de ação rescisória, pelo fato de que, nessa hipótese, nem há a necessidade de enquadramento em algum dos incisos do art. 966, pelo vício contido na ausência da entidade, já ser autorizante para tanto.

No caso de simulação ou colusão, o Ministério Público pode intentar a ação rescisória, por mais que não contenha o interesse específico naquela situação jurídica, mas pode propor tal demanda para retirar aquela questão jurídica, sobre a qual não foi ouvido, mas havia obrigação de sê-lo.

Ainda tem legitimidade para intentar a ação rescisória ente ou entidade que não foram ouvidas no processo em que lhes era obrigatória a intervenção ${ }^{27}$. Nesse caso, houve uma grande inovação, não guardando correspondência com a antiga codificação. Entretanto, essa hipótese deve ser interpretada na modalidade de algum amicus curiae que,

26 “Ao se ocupar da legitimidade ativa para a rescisória, o art. 967 inova em relação ao CPC de 1973, pertinentemente, ao ampliá-la em duas situações. A primeira com relação ao Ministério Público. O inciso III do art. 967 não só reconhece legitimidade para aquela instituição quando o fundamento da rescisória for a simulação ou colusão das partes para fraudar a lei, mas também para evidenciar que sua legitimidade dá-se ‘em outros casos em que se imponha sua atuação' (alínea c). A segunda hipótese reconhece legitimidade ‘àquele que não foi ouvido no processo em que lhe era obrigatória a intervenção', caso típico de litisconsorte necessário preterido (inciso IV do art. 967). Sem prejuízo da legitimidade ativa, o Ministério Público atuará na rescisória, se for o caso, na qualidade de fiscal da ordem jurídica (parágrafo único do art. 967).”. BUENO, Cassio Scarpinella. Novo Código de Processo Civil anotado. São Paulo: Saraiva, 2015. p. 606/607.

27 "A decisão de mérito, quando proferida sem ser ouvido no processo alguém cuja intervenção era obrigatória, é nula, se unitário o litisconsórcio, e ineficaz, se necessário. Em princípio, a hipótese não seria de ação rescisória, porque a nulidade ou a ineficácia pode ser decretada a qualquer tempo. Todavia, ela é admissível, por disposição expressa.” TESHEINER, José Maria Rosa; THAMAY, Rennan Faria Krüger. Ação rescisória no novo Código de Processo Civil. Civil Procedure Review , v. 6, p. 53-104, 2015. p. 67. 
Revista Eletrônica de Direito Processual - REDP.

Rio de Janeiro. Ano 13. Volume 20. Número 1. Janeiro a Abril de 2019

Periódico Quadrimestral da Pós-Graduação Stricto Sensu em Direito Processual da UERJ

Patrono: José Carlos Barbosa Moreira (in mem.). ISSN 1982-7636. pp. 532-566

www.redp.uerj.br

obrigatoriamente $^{28}$, devia ser ouvido e não ocorreu intimação ou manifestação no processo $^{29}$.

Não deve ser confundida essa hipótese de necessidade de intervenção, sem tal ocorrer, com um terceiro que mesmo sapiente da existência dessa, decidiu não fazer parte da demanda. Quem poderia ser parte e, não sendo, não cabe legitimação para o intento da ação rescisória por essa possibilidade de interventor, talvez será possível como terceiro prejudicado, contudo não como interventor.

A hipótese em questão versa sobre obrigatoriedade de intervenção, se há essa modalidade, quem intervém não é parte, somente é ouvida no processo. Se a lei determina uma obrigatoriedade, não cumprida, há legitimidade para a ação rescisória desse ente ignorado.

\subsubsection{Legitimidade passiva da ação rescisória}

O normal da legitimidade passiva será a proposição da ação rescisória contra aquela parte que obteve êxito na demanda, o que podemos chamar do vencedor da ação originária. Se naquela demanda havia um litisconsórcio e todos eles foram beneficiados, a rescisória deve ser intentada com todos esses, formando, portanto, outro litisconsórcio.

No entanto, se a decisão, mesmo com um litisconsórcio, beneficia somente uma daqueles litisconsortes, não há a necessidade de trazê-los todos à nova lide, com a necessidade de incluir como réu somente aquele que foi realmente vencedor e beneficiado na demanda com a decisão a ser rescindida.

\footnotetext{
28 Enunciado n. 339 do FPPC: O CADE e a CVM, caso não tenham sido intimados, quando obrigatório, para participar do processo (art. 118, Lei n. 12.529/2011; art. 31, Lei n. 6.385/1976), têm legitimidade para propor ação rescisória contra a decisão ali proferida, nos termos do inciso IV do art. 967.

29 "É o caso, por exemplo, da Comissão de Valores Mobiliários, cuja intervenção é obrigatória nos processos em que se discutam matéria de sua competência (art. 31, Lei n. 6.385/1976), e do Conselho Administrativo de Defesa Econômica, cuja intervenção é obrigatória nos processos em que se discuta matéria de sua competência (art. 118, Lei n. 12.529/2011). Como se vê, o inciso traz caso em que ente que poderia ter sido amicus curiae tem legitimidade para propor ação rescisória. O dispositivo não se aplica, porém, ao litisconsorte necessário não citado. Note que o texto fala daquele cuja "intervenção" era necessária, não daquele cuja citação era necessária - uma sutileza, mas muito importante. Além disso, o litisconsorte necessário não citado tem de valer-se da querela nullitatis, prevista expressamente no inciso I do $\S 1^{\circ}$ do art. 539, NCPC: é que a falta de citação não é caso de ação rescisória, mas, sim, de querela nullitatis. A falta de citação que gera decisão contrária ao não-citado não é caso de rescindibilidade, mas, sim, de nulidade, cuja decretação se pede pela querela nullitatis." DIDIER JR, Fredie. Nova hipótese de legitimidade para a propositura de ação rescisória. Novo CPC. Art. 979, IV, versão da Câmara dos Deputados. http://www.frediedidier.com.br/editorial/editorial-183/
} 
Revista Eletrônica de Direito Processual - REDP.

Rio de Janeiro. Ano 13. Volume 20. Número 1. Janeiro a Abril de 2019

Periódico Quadrimestral da Pós-Graduação Stricto Sensu em Direito Processual da UERJ

Patrono: José Carlos Barbosa Moreira (in mem.). ISSN 1982-7636. pp. 532-566

www.redp.uerj.br

Se for necessária a citação do sucessor desse envolvido na demanda originária, pelo fato de que o indivíduo não tem mais possibilidades de responder tal demanda, não há negativa, mesmo que haja, portanto, uma mudança no polo da ação rescisória, em relação aquela originária.

Eventual litisconsorte excluído na demanda originária, não sendo alcançado pela decisão de mérito a ser rescindida, não deve ser incluído na ação rescisória ${ }^{30}$.

Os terceiros beneficiados com a decisão transitada em julgado podem ser incluídos no polo passivo da ação rescisória, mas não é o normal e, caso assim for procedido, o autor deve fundamentar tal pleito, com a demonstração da existência do benefício.

Se a demanda originária foi intentada por um substituto processual, ativa ou passivamente, esse que será legítimo para responder a ação rescisória, mantendo, para essa nova demanda, a substituição processual. Se um sindicato intentou a demanda e foi julgada procedente e, tiver vícios possíveis para a proposição de ação rescisória, eventual autor deve propor contra o sindicato ${ }^{31}$, substituto processual por legitimação extraordinária na demanda originária.

Caso a demanda rescisória alcance os honorários advocatícios sucumbenciais, os advogados que perceberam tal quantia devem, de igual modo, serem citados como réus ${ }^{32}$ em tal demanda ação rescisória ${ }^{33}$.

30 BARIONI, Rodrigo. Legitimidade passiva na ação rescisória. Aspectos polêmicos e atuais dos recursos cíveis e assuntos afins. NERY JR., Nelson; WAMBIER, Teresa Arruda Alvirn (coords.). São Paulo: RT, v. 12, 2011. p. 382.

31 MOREIRA, José Carlos Barbosa. Comentários ao código de processo civil. 7. ed. Rio de Janeiro: Forense, v. 05, 1998. p. 173.

32 Não apenas a inclusão do advogado, deve averiguar-se quais os beneficiados pelos honorários, podendo ser para todos os advogados que patrocinaram, somente um ou a própria sociedade advocatícia: "Deverá, pois, checar, nos autos do processo anterior, quem efetivamente levantou os honorários: um único advogado ou os advogados que atuaram na causa; a sociedade de advogados da qual ele ou eles são sócios; a própria parte sem quaisquer ressalvas etc. Apenas depois desta cuidadosa aferição é que deverá ser desenhado o litisconsórcio passivo na ação rescisória, a ser integrado pelos litigantes originários e, ainda, diante da possível extensão objetiva da rescisão, por eventuais terceiros interessados, incluindo-se nessa categoria o advogado ou os advogados, ou, até mesmo, a sociedade de advogados, dependendo de quem tenha efetivamente sido beneficiário da verba de sucumbência.” TUCCI, José Rogério Cruz e. Legitimidade passiva

do advogado na ação rescisória. http://www.conjur.com.br/2017-jun-20/paradoxo-corte-legitimidade-passivaadvogado-acao-rescisoria

33 RECURSO ESPECIAL No 1.651 .057 - CE (2017/0014013-2) RELATOR : MINISTRO MOURA RIBEIRO EMENTA RECURSO ESPECIAL. DIREITO CIVIL E PROCESSUAL CIVIL. AÇÃO RESCISÓRIA. LEGITIMIDADE PASSIVA. LITISCONSÓRCIO PASSIVO NECESSÁRIO ENTRE AQUELE QUE FIGUROU COMO PARTE NO PROCESSO E O ADVOGADO EM FAVOR DE QUEM CONSTITUÍDOS HONORÁRIOS SUCUMBENCIAIS. 1. A legitimidade passiva, na ação rescisória, se estabelece em função do pedido deduzido em juízo. Assim, conforme informado pela teoria da asserção, 


\subsection{Competência para o julgamento da ação rescisória}

A ação rescisória é um exemplo de competência originária dos Tribunais. Não há ação rescisória em juízos de primeiro grau, a competência sempre é de um Tribunal ${ }^{34}$.

Primeiro ponto a ser analisado é a decisão transitada em julgada de primeiro grau, com a competência no seu respectivo Tribunal, estadual ou regional federal, por mais que a decisão impugnada seja uma interlocutória ou uma sentença, ainda assim, a competência será do Tribunal de segundo grau.

Se a decisão impugnada for proferida por um Tribunal, a ação rescisória terá competência, em regra, naquele mesmo Tribunal, porém dependerá do conteúdo da decisão que foi proferida.

Caso seja a decisão transitada em julgado - monocrática ou acórdão - prolatada pelo Tribunal de segundo grau, esse mesmo é o competente para o julgamento da ação rescisória, independentemente do conteúdo. A competência para a rescisão de acórdãos de mérito transitados em julgados em Tribunal de Justiça Estadual ${ }^{35}$ ou Regionais

devem figurar no polo passivo da demanda todos aqueles (e somente aqueles) que foram concretamente beneficiados pela sentença rescindenda. 2. A ação rescisória, quando busca desconstituir sentença condenatória que fixou honorários advocatícios sucumbenciais deve ser proposta não apenas contra o titular do crédito principal formado em juízo, mas também contra o advogado em favor de quem foi fixada a verba honorária de sucumbência, porque detém, com exclusividade, a sua titularidade. 3. Recurso especial provido. ACÓRDÃO Vistos, relatados e discutidos os autos em que são partes as acima indicadas, acordam os Senhores Ministros da Terceira Turma do Superior Tribunal de Justiça, por unanimidade, em dar provimento ao recurso especial, nos termos do voto do Sr. Ministro Relator. Os Srs. Ministros Nancy Andrighi, Paulo de Tarso Sanseverino e Marco Aurélio Bellizze (Presidente) votaram com o Sr. Ministro Relator. Ausente, justificadamente, o Sr. Ministro Ricardo Villas Bôas Cueva. Brasília, 16 de maio de 2017 MINISTRO MOURA RIBEIRO Relator

$34 \quad$ "O juízo competente para processar e julgar a ação rescisória deve ser hierarquicamente superior ao juízo que proferiu a sentença ou acórdão rescindendo. Proferida a sentença por juízo de primeiro grau, é competente para a rescisória o tribunal que teria competência recursal para examinar a matéria, se tivesse havido interposição de recurso. Tratando-se de rescisória de acórdão, é competente o mesmo tribunal que proferiu o acórdão impugnado, devendo ser processada e julgada por órgão colegiado mais ampliado do que o que proferiu o acórdão. Vale dizer, se o órgão (turma julgadora de três juízes) prolatou o acórdão rescindendo, o mesmo órgão em composição ampliada (turma julgadora de cinco juízes) ou outro (turma, grupo de câmaras reunidas etc.), é que tem competência para o processamento e julgamento da rescisória. Trata-se de competência originária de tribunal em razão da matéria.” BARROS, Evandro Silva. Coisa julgada inconstitucional e limitação temporal para a propositura da ação rescisória. Revista de Direito Constitucional e Internacional. São Paulo: Revista dos Tribunais, n. 47, p. 55-98, abr/jun., 2004. p. 81.

35 A competência da ação rescisória de cada tribunal de justiça é delineada por leis de organização judiciária dentro de cada estado. 
Revista Eletrônica de Direito Processual - REDP.

Rio de Janeiro. Ano 13. Volume 20. Número 1. Janeiro a Abril de 2019

Periódico Quadrimestral da Pós-Graduação Stricto Sensu em Direito Processual da UERJ

Patrono: José Carlos Barbosa Moreira (in mem.). ISSN 1982-7636. pp. 532-566

www.redp.uerj.br

Federais $^{36}$ são desses próprios Tribunais e, independentemente se for recursal ou em competência originária.

Por outro lado, em decisão de Tribunal Superior transitada em julgado, a regra não é tão clara, com a necessidade de averiguação material do conteúdo do acórdão. Nessa hipótese, tanto no STJ ou no STF, a primeira regra é sobre a competência originária, caso uma decisão de processo dessa feita transitar em julgado no próprio Tribunal, sem nenhum recurso, evidentemente, o respectivo Tribunal Superior será o competente para tal julgamento. A decisão proferida no STF, com base na determinação do art. 102, I, alínea J, da Constituição Federal ${ }^{37}$, terá, como competente o mesmo Tribunal. De igual modo, quando a decisão é proferida no STJ, esse é o Tribunal competente para a discussão sobre a possível rescisão, conforme art. 105, I, alínea E, também do texto constitucional ${ }^{38}$.

No entanto, no tocante aos Tribunais Superiores a regra não é tão fácil, mediante o conteúdo ali analisado. Se o acórdão dos Tribunais Superiores for oriundo do julgamento de um recurso excepcional, dependerá da amplitude material ali existente. Por exemplo, caso haja um acórdão do STJ, apreciando a admissibilidade de recurso excepcional, se o conteúdo for negativo, não adentrando ao mérito da questão, deixando de enfrentar os eventuais vícios da decisão meritória, a competência continua a ser do Tribunal de segundo grau, pelo fato de que a sua decisão sobre o mérito foi a última decisão no processo.

O Tribunal Superior, nessa hipótese, não tem a competência para julgar a rescisória pelo fato de não ser o responsável pelo vício na decisão meritória, pela sua decisão ter apreciado somente questões processuais, não tendo, portanto, julgado a matéria viciada, pelo recurso excepcional não ter admissibilidade positiva. $O$ pronunciamento superior não julgou o mérito do recurso, não transferindo a competência para esse tribunal, permanecendo com o Tribunal anterior, aquele que julgou o mérito da demanda.

\footnotetext{
36 Constituição Federal - Art. 108. Compete aos Tribunais Regionais Federais: I - processar e julgar, originariamente: b) as revisões criminais e as ações rescisórias de julgados seus ou dos juízes federais da região;

37 Constituição Federal - Art. 102. Compete ao Supremo Tribunal Federal, precipuamente, a guarda da Constituição, cabendo-lhe: I - processar e julgar, originariamente j) a revisão criminal e a ação rescisória de seus julgados;

38 Constituição Federal - Art. 105. Compete ao Superior Tribunal de Justiça: I - processar e julgar, originariamente: e) as revisões criminais e as ações rescisórias de seus julgados;
} 
Revista Eletrônica de Direito Processual - REDP.

Rio de Janeiro. Ano 13. Volume 20. Número 1. Janeiro a Abril de 2019

Periódico Quadrimestral da Pós-Graduação Stricto Sensu em Direito Processual da UERJ

Patrono: José Carlos Barbosa Moreira (in mem.). ISSN 1982-7636. pp. 532-566

www.redp.uerj.br

Desse modo, ainda que a decisão transitada em julgado seja a do Tribunal Superior, o autor deve analisar qual a última decisão de mérito da demanda, para, a partir de tal análise, defina a competência correta para tal proposição da demanda rescisória.

Por outro lado, se o acórdão do Tribunal Superior analisou o vício, sendo responsável ou não por tal ato, com a confirmação desse na sua decisão, a competência será desse Tribunal.

\subsection{Hipóteses de cabimento da ação rescisória}

A coisa julgada material tem, pela sua própria existência, imutabilidade. O legislador instituiu hipóteses excepcionais de cabimento de uma ação que visa desfazer essa coisa julgada material. Uma evidente relativização da coisa julgada. Entretanto, somente em caráter excepcional, com vícios graves na decisão, em regra, de mérito.

A possibilidade de reversão da coisa julgada material é pequena e taxativa, somente hipóteses constantes no art. 966 podem relativizar a coisa julgada material. Não é um desrespeito à coisa julgada, mas uma forma de garantir a segurança jurídica da produção de efeitos de decisões transitadas em julgado que contêm vícios graves em sua formação. Vícios que a legislação processual imputa como inaceitáveis, a ponto de relativizar o próprio trânsito em julgado.

O rol constante no art. 966 é taxativo, somente essas hipóteses possibilitam a relativização da coisa julgada material e, portanto, a sua rescisão. Vícios existentes na decisão transitada em julgado não constantes ou equiparados aos desse artigo não possibilitam a ação rescisória.

A ação rescisória é possível quando: se verificar que foi proferida por força de prevaricação, concussão ou corrupção do juiz; for proferida por juiz impedido ou por juízo absolutamente incompetente; resultar de dolo ou coação da parte vencedora em detrimento da parte vencida ou, ainda, de simulação ou colusão entre as partes, a fim de fraudar a lei; ofender a coisa julgada; violar manifestamente norma jurídica; for fundada em prova cuja falsidade tenha sido apurada em processo criminal ou venha a ser demonstrada na própria ação rescisória; obtiver o autor, posteriormente ao trânsito em julgado, prova nova cuja existência ignorava ou de que não pôde fazer uso, capaz, por si só, de lhe assegurar pronunciamento favorável; for fundada em erro de fato verificável do exame dos autos. 


\section{AMPLITUDE DA IMPUGNAÇÃO: AÇÃO RESCISÓRIA TOTAL OU PARCIAL}

A ação rescisória tem por finalidade impugnar uma decisão de mérito transitada em julgado, mas não há imposição pela impugnação ser total da decisão, em toda a sua fundamentação ou pedido.

Desse modo, na ação rescisória, pode-se impugnar somente parte da decisão, não necessitando do pleito pela rescisão da totalidade decisória. O art. 966, § $3^{\circ}$ prevê exatamente essa possibilidade, concedendo ao autor da ação rescisória a liberdade de escolha sobre a impugnação de toda a decisão ou somente de parte dela.

A ação rescisória, portanto, tem o condão de pleitear a rescisão integral da decisão, com a total inexistência da decisão impugnada, em caso de procedência ou, somente parte dessa ${ }^{39}$, permitindo, por conseguinte, a manutenção daquilo que não foi impugnado, justamente por continuar, essa parte, transitada em julgado.

A priori pertence ao autor o direito e a liberdade da delimitação da própria ação rescisória e sua impugnabilidade, na relação desta com a decisão que pleiteia ser rescindida. No entanto, depende também da própria decisão transitada em julgado e a quantidade de capítulos que esta contiver, pelo fato de que há a possibilidade de conter somente um capítulo decisório, o que importaria em rescindir, necessariamente, a decisão inteira.

Por outro lado, com diferentes pontos decisórios, cabe ao autor a definição material impugnativa que será o mérito da ação rescisória.

\footnotetext{
39 "Rescisão de capítulo de sentença. No regime do CPC/73, o STJ pacificou o entendimento de que os diversos capítulos de sentença trânsitos em julgados em instâncias distintas, não faziam coisa julgada material, mas apenas formal, ou seja, o STJ rejeitou a teoria da coisa julgada progressiva, de modo que a via rescisória só se abria após o trânsito em julgado do último capítulo de sentença, inclusive, o termo a quo do prazo decadencial da ação rescisória se daria nesse momento, conforme restou assentado no Enunciado $\mathrm{n}^{\circ}$ 401 de sua Súmula, que estabelece: "O prazo decadencial da ação rescisória só se inicia quando não for cabível qualquer recurso do último pronunciamento judicial”. O CPC/2015, que tem o princípio da razoável duração do processo como uma de suas normas fundamentais (art. $4^{\circ}$ ) e que adotou a técnica do julgamento antecipado parcial do mérito (art. 356), andou bem ao permitir a rescisão dos capítulos de sentença, à medida que forem se tornando definitivos ( $\S 3^{\circ}$, art. 356), tanto assim que o prazo de dois anos contados do trânsito em julgado da última decisão proferida no processo passa a ser o termo ad quem para o ajuizamento da ação rescisória, e não mais o termo a quo (art. 975)." ATAÍDE JR., Jaldemiro Rodrigues de. Comentário ao art. 503. Novo Código de Processo Civil Comentado - Tomo III. Orgs: RIBEIRO, Sergio Luiz Almeida; GOUVEIA FILHO, Roberto Pinheiro Campos; PANTALEÃO, Izabel Cristina; GOUVEIA, Lucio Grassi de. Ed. Lualri,São Paulo, 2017. p. 278.
} 
Revista Eletrônica de Direito Processual - REDP.

Rio de Janeiro. Ano 13. Volume 20. Número 1. Janeiro a Abril de 2019

Periódico Quadrimestral da Pós-Graduação Stricto Sensu em Direito Processual da UERJ

Patrono: José Carlos Barbosa Moreira (in mem.). ISSN 1982-7636. pp. 532-566

www.redp.uerj.br

\subsection{Os capítulos da decisão e a ação rescisória}

Na doutrina do CPC/73 já era admissível a existência, dentro de uma sentença, de capítulos diversos, principalmente pela doutrina de Dinamarco sobre a questão ${ }^{40}$.

A existência de capítulos de sentença é mais visualizável pela possibilidade de cumulação de pedidos, o que enseja uma junção material de pleitos, com determinada independência entre as questões a serem decididas, contudo não serão somente as matérias autônomas que serão tidas como capítulos de uma sentença, podendo, mesmo numa demanda com um só pedido, esta conter diversos capítulos decisórios diferentes ${ }^{41}$.

Para Dinamarco, capítulos de sentença são "como as partes em que ideologicamente se decompõe o decisório de uma sentença ou acórdão, cada uma delas contendo o julgamento de uma pretensão distinta ${ }^{42}$." Para que seja um capítulo diverso, aquele ponto material deve ter uma distinção de pretensão do que o todo ou outros pontos.

$\mathrm{Na}$ transposição para o novel ordenamento, a teoria dos capítulos da sentença passa a ser da decisão, pelo fato da sentença ser uma das formas de decisão que resolve a lide, podendo, de igual maneira, uma decisão interlocutória, nos moldes do art. 356, decidir parte do mérito. Dessa feita, pertinente é a visão de capítulos da decisão ${ }^{43}$.

No tocante à ação rescisória, se a decisão tem capítulos diferentes, com matérias diversas, quando houver a existência de um vício na decisão, pode tal demanda versar

\footnotetext{
40 DINAMARCO, Cândido Rangel. Capítulos de sentença. 4. ed. São Paulo: Malheiros, 2009. p. 666.

41 "A teoria dos capítulos decisórios parte de uma cisão vertical dos dispositivos de uma determinada decisão judicial. Cada um desses capítulos, que tanto pode ter natureza processual como material, será regido por pressupostos autônomos. A possibilidade de um determinado capítulo poder ou não ser alvo de uma ação específica é irrelevante para que seja considerado como capítulo, bastando que conste decisão sobre o tema." PEIXOTO, Ravi; SILVEIRA, Marcelo Pichioli da. Ação rescisória e competência: novos e velhos problemas. Revista Brasileira de Direito Processual - RBDPro. Belo Horizonte, ano 24, n. 96, out. / dez. 2016. p. 222. 42 DINAMARCO, Cândido Rangel. Capítulos de sentença. 4. ed. São Paulo: Malheiros, 2009. p. 666. 43 "Fez-se necessário falar em capítulo de decisão, e não apenas de sentença, porque o novo CPC admite o julgamento parcial do mérito da causa por meio da decisão interlocutória de mérito, que, obviamente, também terá capítulos. A ação rescisória contra capítulo de decisão pode ser proposta tão logo transite em julgado esse capítulo, uma vez que, no novo Código, não há previsão do termo inicial do prazo da rescisória, mas sim do termo final, que se dá em dois anos do trânsito em julgado da última decisão do processo.” CRAMER, Ronaldo. Comentário ao art. 966. CABRAL, Antonio Passo, CRAMER, Ronaldo (orgs.). Comentários ao novo código de processo civil, $2^{\mathrm{a}}$ edição. Método, 06/2016. [Minha Biblioteca]. Retirado de https://integrada.minhabiblioteca.com.br/\#/books/9788530971441/
} 
Revista Eletrônica de Direito Processual - REDP.

Rio de Janeiro. Ano 13. Volume 20. Número 1. Janeiro a Abril de 2019

Periódico Quadrimestral da Pós-Graduação Stricto Sensu em Direito Processual da UERJ

Patrono: José Carlos Barbosa Moreira (in mem.). ISSN 1982-7636. pp. 532-566

www.redp.uerj.br

somente sobre o capítulo atingido pelo vício, sem a obrigatoriedade de impugnação sobre todos os pontos da decisão, conforme a previsão do art. $966, \S 3^{\circ}$.

No entanto, há de se imaginar a dependência sobre tais capítulos, muito além do que a simples autonomia entre eles. A decisão tem capítulos autônomos, como, por exemplo, a condenação em honorários advocatícios, ocorrendo independentemente do resultado da decisão e, em momento posterior. Mas, além de autônomo, o capítulo pode ser independente ou não, com a necessidade de julgamento, mesmo que outro ponto não seja julgado.

Um exemplo dessa dependência seria o julgamento sobre os juros daquela condenação, somente ocorrendo em momento posterior à própria condenação e se existente essa, uma vez ocorrendo tal, o capítulo dos juros é autônomo ao da condenação, mas não independente.

Essa diferenciação é importante para o julgamento da ação rescisória e o alcance material possível. Se os capítulos são, além de autônomos, independentes, a ação rescisória a ser intentada sobre um capítulo, em nada atinge a outra, pela independência da matéria.

De modo diverso, se os capítulos são autônomos, contudo dependentes entre si, a ação rescisória, mesmo com a escolha de atingir somente um capítulo, atinge os demais, não por sua impugnabilidade, mas pela conjunção e relação de dependência dos capítulos da decisão.

Não há, nessa situação dos capítulos da decisão, a necessidade da impugnação, via ação rescisória, para a anulação da decisão integralmente, se o vício somente influencia parte da decisão. Todavia, é possível que mesmo que existam capítulos diversos, esses sejam impactados pela ação rescisória sobre outro capítulo, mas somente se houver dependência.

\subsection{A decisão parcial de mérito e a ação rescisória}

O CPC/2015 trouxe a possibilidade da prolação de decisão parcial de mérito, disciplinada no art. 356. Esse instituto trata de maneira bastante inovadora a permissão da decisão meritória ser cindida durante o processo, com a possibilidade de que haja 
Revista Eletrônica de Direito Processual - REDP.

Rio de Janeiro. Ano 13. Volume 20. Número 1. Janeiro a Abril de 2019

Periódico Quadrimestral da Pós-Graduação Stricto Sensu em Direito Processual da UERJ

Patrono: José Carlos Barbosa Moreira (in mem.). ISSN 1982-7636. pp. 532-566

www.redp.uerj.br

uma decisão interlocutória com total conteúdo meritório. A decisão parcial ${ }^{44}$ é uma espécie dentro do gênero de julgamento antecipado do mérito, contudo somente alcança parte da demanda, um determinado pedido ${ }^{45}$ ou um capítulo da ação.

Essa parte da demanda, com uma decisão própria e em momento diverso dos demais capítulos de cognição, detém, necessariamente, uma independência quanto ao restante da demanda, ensejando uma recorribilidade própria e preclusiva, via agravo de instrumento $^{46}$. E, ainda, se tal recurso não for interposto, a decisão transita em julgado, formando uma coisa julgada material e, por conseguinte, uma decisão plenamente rescindível, caso incorra em algum dos vícios do art. 966 em sua prolação.

Ou seja, dessa decisão interlocutória parcial de mérito é cabível ação rescisória.

A dúvida, na verdade, é posterior: qual o momento de início do prazo e cabimento da ação rescisória? O art. 975 dispõe sobre a contagem do prazo de dois anos para a proposição da ação rescisória, sendo a partir do trânsito em julgado da última decisão proferida no processo. Desse modo, na demanda que teve a decisão parcial de mérito, ainda haverá uma sentença sobre outro pedido ou parte desse, o que importaria em conter uma última decisão.

O início do prazo será a partir do trânsito em julgado da decisão parcial de mérito ou da decisão final da demanda? Optamos pela primeira hipótese, pelo entendimento de que a decisão parcial de mérito ensejaria uma nova demanda, como uma descumulação da demanda, importando em uma bipartição processual e cognitiva, com, agora, duas ou mais demandas no lugar daquela inicial que cumulava diversas.

\footnotetext{
44 "uma decisão de mérito, fundada em cognição exauriente, proferida após a fase de saneamento do processo, em que o magistrado reconhece a desnecessidade de produção de mais provas em audiência." DIDIER JR, Fredie. Curso de direito processual civil: teoria geral do processo e processo de conhecimento. 17 ed. Salvador. JusPodivm. 2015. p. 688.

45 "O desmembramento do julgamento de mérito em pronunciamentos distintos pressupõe que haja cumulação própria e simples de pedidos, que é aquela em que o autor formula mais de um pedido, no mesmo processo, esperando que todos sejam acolhidos simultaneamente (art. 327). Nessa espécie de cumulação, inexistente dependência lógica entre os pedidos, de maneira que é possível, por exemplo, que o réu reconheça a procedência jurídica de um deles e impugne os demais. A fragmentação do julgamento de mérito pode ocorre, ainda quando há formulação de um pedido, que permite ser decomposto." WAMBIER, Teresa Arruda Alvim. CONCEIÇÃO, Maria Lúcia Lins. RIBEIRO, Leonardo Ferres da Silva. MELLO, Rogério Licastro Torres de. Primeiros comentários ao novo código de processo civil. $1^{\mathrm{a}}$. Ed, São Paulo: RT. 2015. p. 620.

$46 \quad$ Sobre o assunto da recorribilidade da decisão parcial de mérito: LEMOS, Vinicius Silva. O agravo de instrumento contra decisão parcial de mérito. Revista de Processo, v. 259, p. 275-303, 2016.
} 
Revista Eletrônica de Direito Processual - REDP.

Rio de Janeiro. Ano 13. Volume 20. Número 1. Janeiro a Abril de 2019

Periódico Quadrimestral da Pós-Graduação Stricto Sensu em Direito Processual da UERJ

Patrono: José Carlos Barbosa Moreira (in mem.). ISSN 1982-7636. pp. 532-566

www.redp.uerj.br

Diante desse pensamento, não há dúvidas sobre o cabimento da ação rescisória sobre a decisão parcial de mérito e, ainda, com a visão de que o prazo começa a contar logo após o seu próprio trânsito em julgado ${ }^{47}$.

\subsection{A ação rescisória de decisão prejudicial transitada em julgado}

O CPC/2015 trouxe como uma de suas novidades a possibilidade das decisões incidentais transitarem em julgado, fato que não era possível no ordenamento anterior. Ou seja, existe, agora, a coisa julgada prejudicial.

Numa demanda, além das questões meritórias, podem existir outras que não são atinentes ao bem da vida pleiteado em juízo, contudo que devem ser resolvidas para permitir a análise de mérito. Essas são as chamadas prejudiciais de mérito ${ }^{48}$, questões incidentais que impedem o julgamento do mérito sem a sua análise e, ainda, tem o condão de influenciar o resultado da análise meritória.

O nome prejudicial de mérito é pertinente pela influência que sua resolução e resultado podem ocasionar ao mérito da demanda. Essa definição da questão incidental transita em julgado? Essa é a inovação proposta pelo art. 503, $\S 1^{\circ}$, ao incluir tal questão dentre aquelas que formam coisa julgada, contudo para que seja possível tal ponto, deve ater-se ao cumprimento de determinados requisitos, como: dessa resolução depender o julgamento do mérito; a seu respeito tiver havido contraditório prévio e efetivo, não se aplicando no caso de revelia; o juízo tiver competência em razão da matéria e da pessoa para resolvê-la como questão principal; a limitação da possibilidade probatória.

47 "Existem duas correntes desde a interpretação do texto do CPC/73 e que devem se manter no CPC/2015. A primeira defende que o prazo só começa a ser contado da última decisão proferida no processo, independentemente do momento em que transitem em julgado as decisões. A segunda defende que os prazos para a interposição das ações rescisórias podem ser contados de formas distintas, a depender do momento do trânsito em julgado do capítulo que se deseja rescindir, salvo exceções.” PEIXOTO, Ravi. Ação rescisória e capítulo de sentença: a análise de uma relação conturbada a partir do CPC/2015. Coleção Novo CPC Doutrina Selecionada - v.6 - Processo nos Tribunais e Meios de Impugnação às Decisões Judiciais. Orgs: DIDIER JR., Fredie; FREIRE, Alexandre; MACEDO, Lucas Buril de; PEIXOTO, Ravi. Salvador: JusPodivm, 2015. p. 165.

48 "A cognição, então, incide sobre as questões postas ao magistrado. Essas questões possuem diversos planos de análise pela doutrina: questões de fato e de direito, questões subordinadas e subordinantes, questões principais e incidentes, questões preliminares e prejudiciais.” MINAMI, Marcos; PEIXOTO, Ravi. Da questão prejudicial incidental constitucional no STF e o novo regime de coisa julgada. Revista de Processo, v. 263, p. 77-104, 2017. p. 80. 
Revista Eletrônica de Direito Processual - REDP.

Rio de Janeiro. Ano 13. Volume 20. Número 1. Janeiro a Abril de 2019

Periódico Quadrimestral da Pós-Graduação Stricto Sensu em Direito Processual da UERJ

Patrono: José Carlos Barbosa Moreira (in mem.). ISSN 1982-7636. pp. 532-566

www.redp.uerj.br

As decisões prejudiciais, ao cumprirem tais requisitos ${ }^{49}$, tornam-se igualmente imutáveis. A dúvida é sobre a amplitude e cabimento da ação rescisória: essa demanda pode impugnar tal questão prejudicial? A situação parece simples, apesar de não disposta nos dispositivos ${ }^{50}$ da ação rescisória, mas se a decisão sobre a questão prejudicial cumprir os requisitos acima desposados, conforme o disposto no art. 503, $\S$ $1^{\circ}$, ao tornar-se imutável, devido ao trânsito em julgado, não pode mais se discutido em outra demanda, sendo cabível ${ }^{51}$, portanto, a ação rescisória para tanto.

O cuidado deve subsistir, primeiro, na verificação se tal questão foi resolvida e, posteriormente, se essa resolução cumpriu os requisitos pertinentes para a formação de coisa julgada prejudicial rescindível. Em modo diverso, na ausência de qualquer requisito, nova demanda pode ser proposta sobre tal questão, o que, mesmo existindo um vício na decisão transitada em julgada, impossibilita o cabimento da ação rescisória.

\subsection{Ações rescisórias em uma mesma demanda sobre decisões de mérito diversas ou coisa julgada progressiva}

Com a decisão, em uma demanda, contendo diversos capítulos, há a possibilidade de que os trânsitos em julgados ocorram, para cada conteúdo decisório, em momentos processuais diversos e, ainda, sobre decisões diferentes. Tal situação ocorreria sobre

\footnotetext{
49 "Isso significa que a estabilização pela res judicata pode ocorrer independentemente da natureza da questão prejudicial. Basta que sejam cumpridos cumulativamente os requisitos legais." SILVA, Ricardo Alexandre. Limites objetivos da coisa julgada e questões prejudiciais. Tese (Doutorado em Direito) Universidade Federal do Paraná. 2016. p. 147.

50 Gouveia Filho fala sobre a coisa julgada independer da formalidade para tanto, de qualquer pronúncia sobre tal fato na parte dispositiva, somente com a necessidade de enfrentamento da matéria na fundamentação, o qual concordamos: "Independentemente de qualquer pronúncia judicial, haverá, presentes os pressupostos, o efeito da indiscutibilidade. Este, como sói ser dito, ocorre por "força de lei", porquanto produto de uma compulsoriedade. Se o texto aprovado denota uma situação menos burocrática, já que o efeito ocorre automaticamente; por outro lado, pode dar causa inseguranças jurídicas, como será observado em item próprio." No entanto, Gouveia Filho entende que seria interessante que houvesse tal pronúncia. "Outra consideração relevante é de que a compulsoriedade da formação coisa julgada não impede o juiz, independentemente de qualquer pedido da parte, se pronunciar sobre a questão prejudicial, declarando-a no dispositivo. Pelo contrário, tal medida terá a importante função de esclarecimento." GOUVEIA FILHO, Roberto Pinheiro Campos. Comentário ao art. 503. Novo Código de Processo Civil Comentado - Tomo II (art. 318 ao art. 770). Orgs: RIBEIRO, Sergio Luiz Almeida; GOUVEIA FILHO, Roberto Pinheiro Campos; PANTALEÃO, Izabel Cristina; GOUVEIA, Lucio Grassi de. Ed. Lualri,São Paulo, 2017. p. 294/295.

51 Enunciado $\mathrm{n}^{\circ} .338$ do FPPC: Cabe ação rescisória para desconstituir a coisa julgada formada sobre a resolução expressa da questão prejudicial incidental.
} 
Revista Eletrônica de Direito Processual - REDP.

Rio de Janeiro. Ano 13. Volume 20. Número 1. Janeiro a Abril de 2019

Periódico Quadrimestral da Pós-Graduação Stricto Sensu em Direito Processual da UERJ

Patrono: José Carlos Barbosa Moreira (in mem.). ISSN 1982-7636. pp. 532-566

www.redp.uerj.br

uma sentença com dois capítulos ${ }^{52}$ e, somente um deles foi impugnado via apelação, com a outra parte, obviamente, transitando em julgado. Julgado o recurso em seu mérito, teremos, portanto, dois momentos decisórios passíveis, futuramente, de ação rescisória: um capítulo da sentença não impugnado; e um capítulo do acórdão da apelação.

Nessa hipótese, teremos decisões diferentes, dentro da mesma demanda, para serem impugnáveis via ação rescisória, o que é plenamente possível. Todavia, pertinente verificar-se a questão da competência para a proposição rescisória, pela possibilidade de que as decisões não contenham o mesmo órgão como competente para julgar tal ação.

A ação rescisória, como veremos em subcapítulo próprio de competência, será proposta perante Tribunal, contudo depende da decisão a ser impugnada: no Tribunal de segundo grau, se for sentença, decisão interlocutória parcial ou acórdão desse mesmo Tribunal; se o acórdão for de Tribunal Superior - STJ ou STF, a competência será desse também.

Para a definição da competência, há de se averiguar qual a última decisão na demanda com caráter substitutivo, ou seja, que realmente decidiu a questão a ser rescindível $^{53}$. E, sobre o presente subcapítulo, se houver em uma demanda dois capítulos transitados em julgado em diferentes decisões, o pretenso autor da ação rescisória deve atentar-se, detalhadamente, sobre a competência.

Essa parte é importante para a definição se poderá impugnar todos os capítulos na mesma ação rescisória ou se, necessariamente, deverá propor duas ou mais ações rescisórias.

Para a primeira hipótese, se os conteúdos transitados em julgado foram provenientes, ambos, de sentença ou acórdão de segunda grau, há a possibilidade de cumulação, na mesma ação rescisória, dos pedidos rescindíveis de decisões diversas, na combinação

\footnotetext{
52 "Este dispositivo deve ser analisado, a meu ver, especialmente nos casos de interposição de recursos parciais (impugnação de partes de uma única decisão). Assim, os capítulos não impugnados de um pronunciamento judicial podem, desde já e dependendo do caso concreto, ensejar execução definitiva, mesmo inexistindo efetivamente o trânsito em julgado total do decisum." ARAÚJO, José Henrique Mouta. Decisão rescindível e o novo CPC: aspectos polêmicos e atuais. Revista Jurídica Luso-brasileira , v. 4, p. 683-708, 2015. p. 688.

53 Enunciado n 337 do FPPC: A competência para processar a ação rescisória contra capítulo de decisão deverá considerar o órgão jurisdicional que proferiu o capítulo rescindendo.
} 
Revista Eletrônica de Direito Processual - REDP.

Rio de Janeiro. Ano 13. Volume 20. Número 1. Janeiro a Abril de 2019

Periódico Quadrimestral da Pós-Graduação Stricto Sensu em Direito Processual da UERJ

Patrono: José Carlos Barbosa Moreira (in mem.). ISSN 1982-7636. pp. 532-566

www.redp.uerj.br

sentença/acórdão de segundo grau. Uma só ação rescisória impugnando decisões diversas, com a necessidade de que o vício seja pertinente a cada decisão.

Na segunda hipótese, as decisões são de graus que não permitem a mesma ação rescisória cumular as impugnações de decisões diversas, como uma sentença e um acórdão de Tribunal Superior, o que imputa ao autor a necessidade de interposição de duas ações rescisórias: uma contra a sentença, perante o Tribunal de segundo grau; outra contra o acórdão do Tribunal Superior, exatamente nesse mesmo órgão.

\section{REFERÊNCIAS BIBLIOGRÁFICAS:}

ARAÚJO, José Henrique Mouta. Decisão rescindível e o novo CPC: aspectos polêmicos e atuais. Revista Jurídica Luso-brasileira, v. 4, p. 683-708, 2015.

ATAÍDE JR., Jaldemiro Rodrigues de. Comentário ao art. 503. Novo Código de Processo Civil Comentado - Tomo III. Orgs: RIBEIRO, Sergio Luiz Almeida; GOUVEIA FILHO, Roberto Pinheiro Campos; PANTALEÃO, Izabel Cristina; GOUVEIA, Lucio Grassi de. Ed. Lualri,São Paulo, 2017.

BARIONI, Rodrigo. Legitimidade passiva na ação rescisória. Aspectos polêmicos e atuais dos recursos cíveis e assuntos afins. NERY JR., Nelson; WAMBIER, Teresa Arruda Alvirn (coords.). São Paulo: RT, v. 12, 2011.

BARROS, Evandro Silva. Coisa julgada inconstitucional e limitação temporal para a propositura da ação rescisória. Revista de Direito Constitucional e Internacional. São Paulo: Revista dos Tribunais, n. 47, p. 55-98, abr/jun., 2004.

BUENO, Cassio Scarpinella. Novo Código de Processo Civil anotado. São Paulo: Saraiva, 2015.

CÂMARA, Alexandre Freitas. Ação rescisória. Rio de Janeiro: Lumen Juris, 2007.

CARVALHO, Fabiano. Ação Rescisória: decisões rescindíveis. São Paulo: Saraiva, 2010.

CRAMER, Ronaldo. Comentário ao art. 966. CABRAL, Antonio Passo, CRAMER, Ronaldo (orgs.). Comentários ao novo código de processo civil, $2^{\mathrm{a}}$ edição. Método, 06/2016. [Minha Biblioteca]. Retirado de https://integrada.minhabiblioteca.com.br/\#/books/9788530971441/ 
Revista Eletrônica de Direito Processual - REDP.

Rio de Janeiro. Ano 13. Volume 20. Número 1. Janeiro a Abril de 2019

Periódico Quadrimestral da Pós-Graduação Stricto Sensu em Direito Processual da UERJ

Patrono: José Carlos Barbosa Moreira (in mem.). ISSN 1982-7636. pp. 532-566 www.redp.uerj.br

CUNHA, Leonardo José Carneiro da; DIDIER JR., Fredie. Curso de direito processual civil. Meios de impugnação às decisões judiciais e processo nos tribunais. $13^{\mathrm{a}} \mathrm{ed}$. Salvador: Jus Podivm, 2016.

DIDIER JR, Fredie. Curso de direito processual civil: teoria geral do processo e processo de conhecimento. 17 ed. Salvador. JusPodivm. 2015.

DIDIER JR, Fredie. Nova hipótese de legitimidade para a propositura de ação rescisória. Novo CPC. Art. 979, IV, versão da Câmara dos Deputados. http://www.frediedidier.com.br/editorial/editorial-183/

DINAMARCO, Cândido Rangel. Nova era do processo civil. $2^{\mathrm{a}}$ ed. São Paulo: Malheiros, 2007.

DINAMARCO, Cândido Rangel. Capítulos de sentença. 4. ed. São Paulo: Malheiros, 2009

GOUVEIA FILHO, Roberto Pinheiro Campos. Comentário ao art. 503. Novo Código de Processo Civil Comentado - Tomo II (art. 318 ao art. 770). Orgs: RIBEIRO, Sergio Luiz Almeida; GOUVEIA FILHO, Roberto Pinheiro Campos; PANTALEÃO, Izabel Cristina; GOUVEIA, Lucio Grassi de. Ed. Lualri,São Paulo, 2017.

HARTMANN, Rodolfo Kronemberg. Curso Completo do Novo Processo Civil. 4a . ed. Niterói: Editora Impetus, 2016.

LEMOS, Vinicius Silva. O agravo de instrumento contra decisão parcial de mérito. Revista de Processo, v. 259, p. 275-303, 2016.

MARINONI, Luiz Guilherme. ARENHART, Sérgio Cruz. MITIDIERO, Daniel. Novo curso de processo civil. v. 2. São Paulo: RT, 2015.

MARINONI, Luiz Guilherme. Coisa Julgada Inconstitucional. 2a.. ed. São Paulo: Revista dos Tribunais, 2010

MAZZEI, Rodrigo; GONÇALVES, Tiago Figueiredo. Primeiras linhas sobre a disciplina da ação rescisória no CPC/15. Coleção Novo CPC - Doutrina Selecionada - v.6 Processo nos Tribunais e Meios de Impugnação às Decisões Judiciais. Orgs: DIDIER JR., Fredie; FREIRE, Alexandre; MACEDO, Lucas Buril de; PEIXOTO, Ravi. Salvador: JusPodivm, 2015.

MEDINA, José Miguel Garcia. Comentário ao art. 966. STRECK, Lenio. (3/2016). Comentários ao código de Processo Civil, $11^{a}$ edição.. [Minha Biblioteca]. Retirado de https://integrada.minhabiblioteca.com.br/\#/books/9788502635609/ 
Revista Eletrônica de Direito Processual - REDP.

Rio de Janeiro. Ano 13. Volume 20. Número 1. Janeiro a Abril de 2019

Periódico Quadrimestral da Pós-Graduação Stricto Sensu em Direito Processual da UERJ

Patrono: José Carlos Barbosa Moreira (in mem.). ISSN 1982-7636. pp. 532-566 www.redp.uerj.br

MINAMI, Marcos; PEIXOTO, Ravi. Da questão prejudicial incidental constitucional no STF e o novo regime de coisa julgada. Revista de Processo, v. 263, p. 77-104, 2017

MOREIRA, José Carlos Barbosa. Comentários ao código de processo civil. 7. ed. Rio de Janeiro: Forense, v. 05, 1998.

PEIXOTO, Ravi. Ação rescisória e capítulo de sentença: a análise de uma relação conturbada a partir do CPC/2015. Coleção Novo CPC - Doutrina Selecionada - v.6 Processo nos Tribunais e Meios de Impugnação às Decisões Judiciais. Orgs: DIDIER JR., Fredie; FREIRE, Alexandre; MACEDO, Lucas Buril de; PEIXOTO, Ravi. Salvador: JusPodivm, 2015.

PEIXOTO, Ravi; SILVEIRA, Marcelo Pichioli da. Ação rescisória e competência: novos e velhos problemas. Revista Brasileira de Direito Processual - RBDPro. Belo Horizonte, ano 24, n. 96, out. / dez. 2016.

SILVA, Ricardo Alexandre. Limites objetivos da coisa julgada e questões prejudiciais. Tese (Doutorado em Direito) - Universidade Federal do Paraná. 2016.

SOUZA, Bernardo Pimentel. Introdução aos recursos cíveis e à ação rescisória. $3^{\mathrm{a}}$ ed., São Paulo: Saraiva, 2004.

TALAMINI, Eduardo; WAMBIER, Luiz Rodrigues. Curso avançado de processo civil: teoria geral do processo e processo de conhecimento. 11. ed. São Paulo/SP: Revista dos Tribunais, 2010.

TESHEINER, José Maria Rosa; THAMAY, Rennan Faria Krüger. Ação rescisória no novo Código de Processo Civil. Civil Procedure Review , v. 6, p. 53-104, 2015.

TUCCI, José Rogério Cruz e. Legitimidade passiva do advogado na ação rescisória. http://www.conjur.com.br/2017-jun-20/paradoxocorte-legitimidade-passiva-advogado-acao-rescisoria

WAMBIER, Teresa Arruda Alvim. CONCEIÇÃO, Maria Lúcia Lins. RIBEIRO, Leonardo Ferres da Silva. MELLO, Rogério Licastro Torres de. Primeiros comentários ao novo código de processo civil. 1ª . Ed, São Paulo: RT. 2015. 